\title{
Petrological and Geochemical Evaluation of the Paleocene-Eocene Lithofacies in Dahomey Embayment, Southwestern Nigeria
}

\author{
Olugbenga A. Boboye, Olusegun J. Omotosho \\ Department of Geology, University of Ibadan, Ibadan, Nigeria \\ Email: oa.boboye@mail.ui.edu.ng, boboyegbenga@yahoo.com
}

How to cite this paper: Boboye, O.A. and Omotosho, O.J. (2017) Petrological and Geochemical Evaluation of the PaleoceneEocene Lithofacies in Dahomey Embayment, Southwestern Nigeria. Open Journal of Geology, 7, 690-719.

https://doi.org/10.4236/ojg.2017.75047

Received: November 30, 2016

Accepted: May 23, 2017

Published: May 26, 2017

Copyright (c) 2017 by authors and Scientific Research Publishing Inc. This work is licensed under the Creative Commons Attribution International License (CC BY 4.0).

http://creativecommons.org/licenses/by/4.0/

\begin{abstract}
The detail mapping and logging of the Ibese area within the Dahomey Basin has revealed the total thickness of the limestone to range between $12.0 \mathrm{~m}$ to $15.0 \mathrm{~m}$. This study is based on qualitative lithologic, spectrochemical analyses via $\mathrm{X}$-ray fluorescence and petrographic indices to understand the lithofacie, chemistry, viability of the sequences and depositional environment. This consists of milky to grey and nodular to massive fossiliferous limestone units while the sand content increases with depth. The composition of the major oxides in the thirty-seven (37) samples from six exploratory wells revealed that $\mathrm{CaO}(51 \%-56 \%), \mathrm{SiO}_{2}(2.6 \%-10.56 \%), \mathrm{Fe}_{2} \mathrm{O}_{3}(0.33 \%-0.94 \%), \mathrm{MgO}$ $\left(0.78 \%-1.02 \%\right.$ and $\mathrm{Al}_{2} \mathrm{O}_{3}(0.72 \%-0.98 \%)$ were the most abundant elements. The trend of the geochemical indices show increase in the percentage composition of $\mathrm{CaO}$, and $\mathrm{MgO}$ down the sequences with high values which defined the depth of diagenetic re-distribution. The percentage composition of $\mathrm{Al}_{2} \mathrm{O}_{3}$, $\mathrm{Fe}_{2} \mathrm{O}_{3}$ and $\mathrm{K}_{2} \mathrm{O}$ are significant indicating continental influence during diagenesis and diverse depositional episodes. The three different microfacies recognized based on depositional texture are shelly biomicrite, shelly biosparmicrite and alga biosparmicrite. The predominance of micrite as the cementing matrix revealed that the rock was deposited in a quiet shallow inner shelf environment occasioned by storm waves.
\end{abstract}

\section{Keywords}

Environment, Petrography, Geochemistry, Diagenesis, X-Ray Fluorescence

\section{Introduction}

The Dahomey Basin is an arcuate extensive basin located within the Gulf of Guinea, West Africa (Figure 1). It extends from the eastern part of Takoradi 


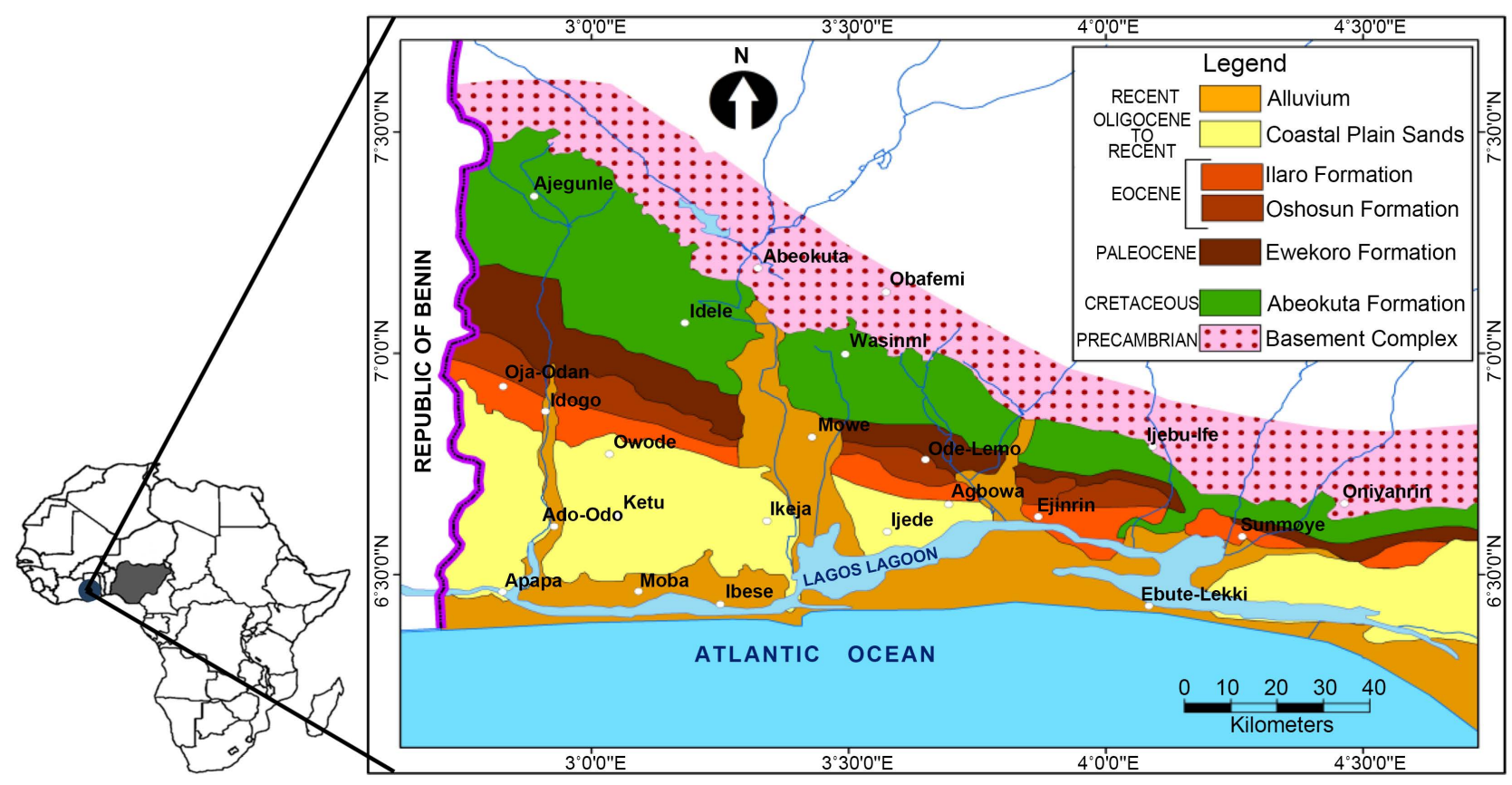

Figure 1. Map of Africa showing the location of Nigeria and the generalized geological map of the eastern. Dahomey Basin (modified after Gebhardt et al. [27]).

Height in Ghana through Togo, Republic of Benin and then terminates at the Okitipupa ridge, south western Nigeria separating it from the Niger Delta. It runs parallel to the coastal states of these countries covering a total area of approximately $49,209 \mathrm{~km}^{2}$ [1]. The states within the basin in the Nigerian sector include Lagos, Ogun, Ondo and Benin and the sediments' thicknesses increase toward the sea (Figure 1). The northern part of the basin in Nigeria is the exposure of the Abeokuta group which unconformably overlying the basement while towards the sea, there is a progressive increase in the thickness of chemical and biochemical sediments such as gypsum, glauconite, limestone and other associated marine deposits which is then capped by coastal sands [2] [3]. Numerous works have been carried out on the Ewekoro and Akinbo formations which are exposed at different sections of eastern part of the Dahomey Basin [3] [4] [5].

Omatsola and Adegoke described the structure and stratigraphy of the Abeokuta formation [6]. Ogbe proposed that the overlying finely laminated shale at the Ewekoro quarry is Akinbo Formation [7]. Ekweozor and other workers studied the origin of tar sands, organic geochemical investigation of bitumen, properties and source rock evaluation of interbedded shale of southwestern Nigeria [8] [9]. They concluded that the tar sand deposits represent the product of reservoir transformation of hydrocarbon by anaerobic micro-organisms. The study of the subsurface in Dahomey Basin of upper Cretaceous and lower Tertiary of Bodashe-1 and Ile paw wells was carried out and concluded that the sediments belong to the Araromi Formation [10], while the use of pebble morphometry associated with the siliciclastic sediments of Abeokuta group was used to deduce their depositional environment [11] [12]. Boboye and Raji reported that the biostratigraphy and petrography of the sequences were deposited in 
quiet shallow marine environments and that the presence of Toweiuscallosus and Coccolithusformosus indicated that Oshosun and Ewekoro Formations were Ypresian and Thanetian to Ypresian age [3]. This rock is a potential hydrocarbon reservoir for the overlying shale while this character of the rock is seen in the Benin Republic sector of the basin, where petroleum is produced at marginal level [3] [13] [14]. The aspect geochemical evaluation, depositional environment and reserve estimation of limestone deposit were also reported around Orimogija and Okeluse areas of eastern Dahomey Embayment [15] [16]. However, this study focus on the distribution of diverse lithofacies, genetic description of the Ewekoro Formation with emphasis on the limestone and what characterize the environment of its deposition, the extent of diagenesis, biological influence on the chemistry of the units, major elemental composition, post depositional processes and their viability in determining its economic values.

\section{Stratigraphy of the Dahomey Basin}

The Dahomey Basin is described by an extensive wedge of Cretaceous to Recent sediments which lies unconformably on the basement [1]. Theses rocks are upper Cretaceous Post Santonian which also outcrops in the River Niger, Bida Basin and the eastern sector part of the Anambra Basin down to the Okitipupa high. In the Dahomey Basin the three stage tectonic evolution allows the stratigraphic sequence to be divided into three sequences namely Precambrian to Triassic intracratonic rocks and Jurassic to lower Cretaceous, Continental to marginal marine rocks representing the pre-transform stage, the lower Cretaceous to late Albian rocks representing the syn-transform stage and Cenomanian to Holocene rocks representing the post-transform stage [9].

The lower Ise Formation which overlies the basement contains conglomerates, coarse to medium grain sandstones and shales that were deposited in continental and deltaic environments. The conglomerates are imbricated and at some locations, ironstones occur [10]. The conglomerates are poorly sorted, micaceous and more or less clayey [1]. This formation which is part of the Abeokuta group can be classified under the groups of rocks formed in the pre-transform stage between Upper Jurassic to Neocomian, [9] [11] [12]. This age is more representative on the offshore part of the basin which may reach about $2000 \mathrm{~m}$ thick though this has not been reached by drilling but geological interpretation have been inferred from various seismic data [13]. This formation also is represented in the Neocomian. Cross bedding is noticeable while the rock is soft and friable [1].

Overlying the Ise Formation of the Abeokuta group is the Afowo Formation which is made up coarse to medium grained sands and interbedded shales, siltstones and claystone with the sandy facies bearing tar while the shales are organic rich [12] [18] (Figure 2).

The lower part of this formation which overlie the Ise Formation is transitional with mixed brackish to marginal horizons that alternate with well sorted, sub-rounded sands indicating a littoral or estuarine near shore environment of 


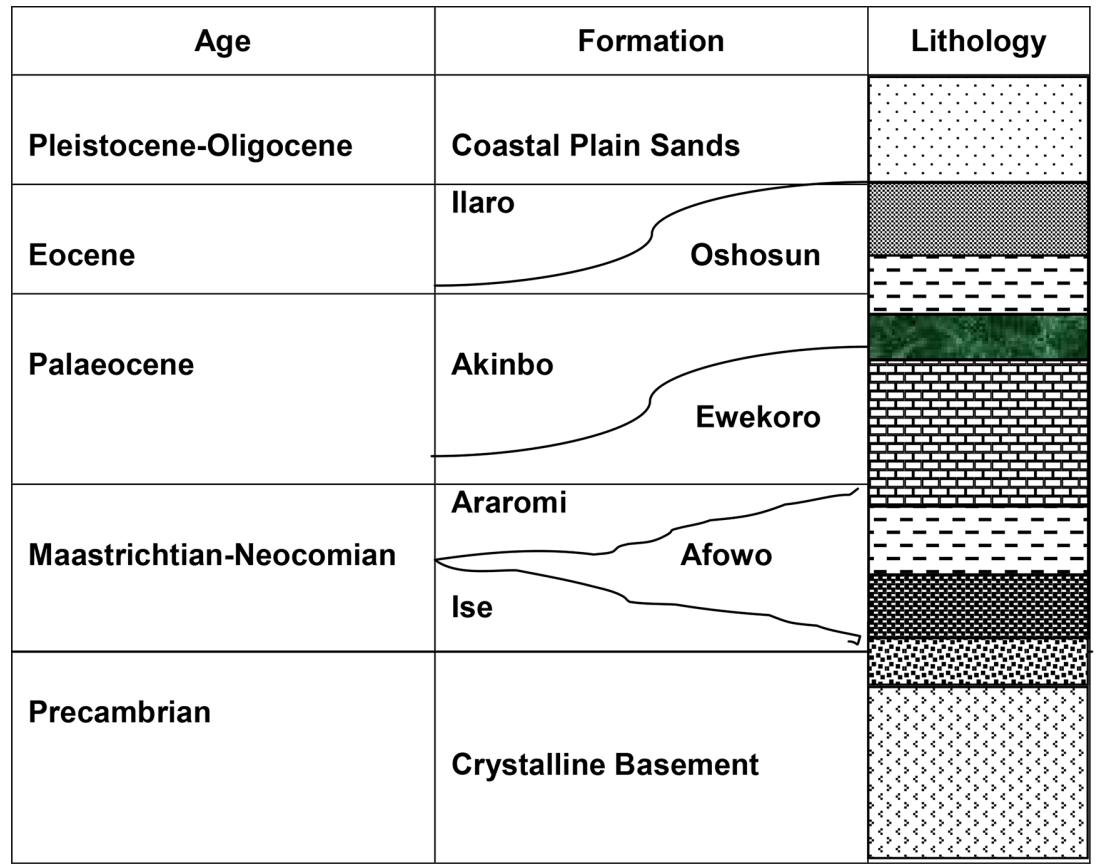

Figure 2. Stratigraphy of Nigerian eastern sector of Dahomey Basin (modified after Omatsola and Adegoke, [4]).

deposition [2]. Brownfield and other workers described fairly sorted sandstone interbedded with shale beds overlying a shale and siltstone sequence deposited as a reworked fan delta in a marginal marine to inner shelf environment [19]. This unit corresponds to the beginning of the post transform stage in the basin and is dated as Turonian. The upper part of this formation grades into Maastrichtian in different parts of the basin [19].

\section{Location of the Study Area and Geology}

The study area is located in Ibese, southwestern Nigeria about $40 \mathrm{~km}$ southwest of Abeokuta where quarrying activities have revealed rocks of diverse ages and lithologies within the basin (Figure 1). The geology as exposed at different road cuts and quarry exposures show the occurrence of lateritic sandy horizon which is the topmost layer. The underlying lithology in this sequence is sandy shale with lateritic concretions which is succeeded by the occurrence of shale. At other sections where weathering is minimal, this layer show glauconitic nodules followed by the occurrence of partially weathered poor fossiliferous limestone units succeeded by a fossiliferous horizon which extends to a significant depth before terminating on marl. Intercalating the marl units are sandy shale and poorly sorted sandstones.

\section{Materials and Methods}

\subsection{Field Study}

The field mapping was carried out in order to determine different rock units and their association within the area. The samples constitute limestone, shale and 
sandstone. A systematic mapping and sampling was adopted at five meters' intervals. The lithostratigraphic descriptive geology of the study area is well described in the quarry site where exposures of the rocks can be studied (Figures 3-9). The rocks are structurally undeformed and strike east west running parallel to the coastline. The rocks association were defined from core samples with the uppermost unit extending up to about $0.7 \mathrm{~m}$.

\subsection{Laboratory Analyses}

The samples were disaggregated and subjected to lithological description and petrography in the laboratory while the samples for the XRF analysis were pulverized into a fine powder. Between $10 \mathrm{mg}-15 \mathrm{mg}$ of the samples were subjected to X-ray fluorescence Spectrometric analysis which was done using the Rigaku XRF Spectrometer with a rhodium $(\mathrm{Rh})$ target. This runs at $50 \mathrm{KV} / 50 \mathrm{~mA}$ with full vacuum and a $25 \mathrm{~mm}$ mask for the analysis of various major oxides with the detectable limits for the major elements which were $0.01 \%$ for $\mathrm{SiO}_{2}, \mathrm{Al}_{2} \mathrm{O}_{3}, \mathrm{CaO}$ and $0.04 \%$ for $\mathrm{Fe}_{2} \mathrm{O}_{3}$ both at $100 \%$ upper limit. The petrographic slides were prepared at the thin section laboratory, where thin sections approximately $30 \mu \mathrm{m}$ thick of the samples were produced for microscopic study.

\section{Results and Discussion}

\subsection{Lithostratigraphy}

The lithofacies that constitute the study area are sandstone, clay, shale, limestone and marl. The sandstones are fine grain with the ferruginized sandy clay units

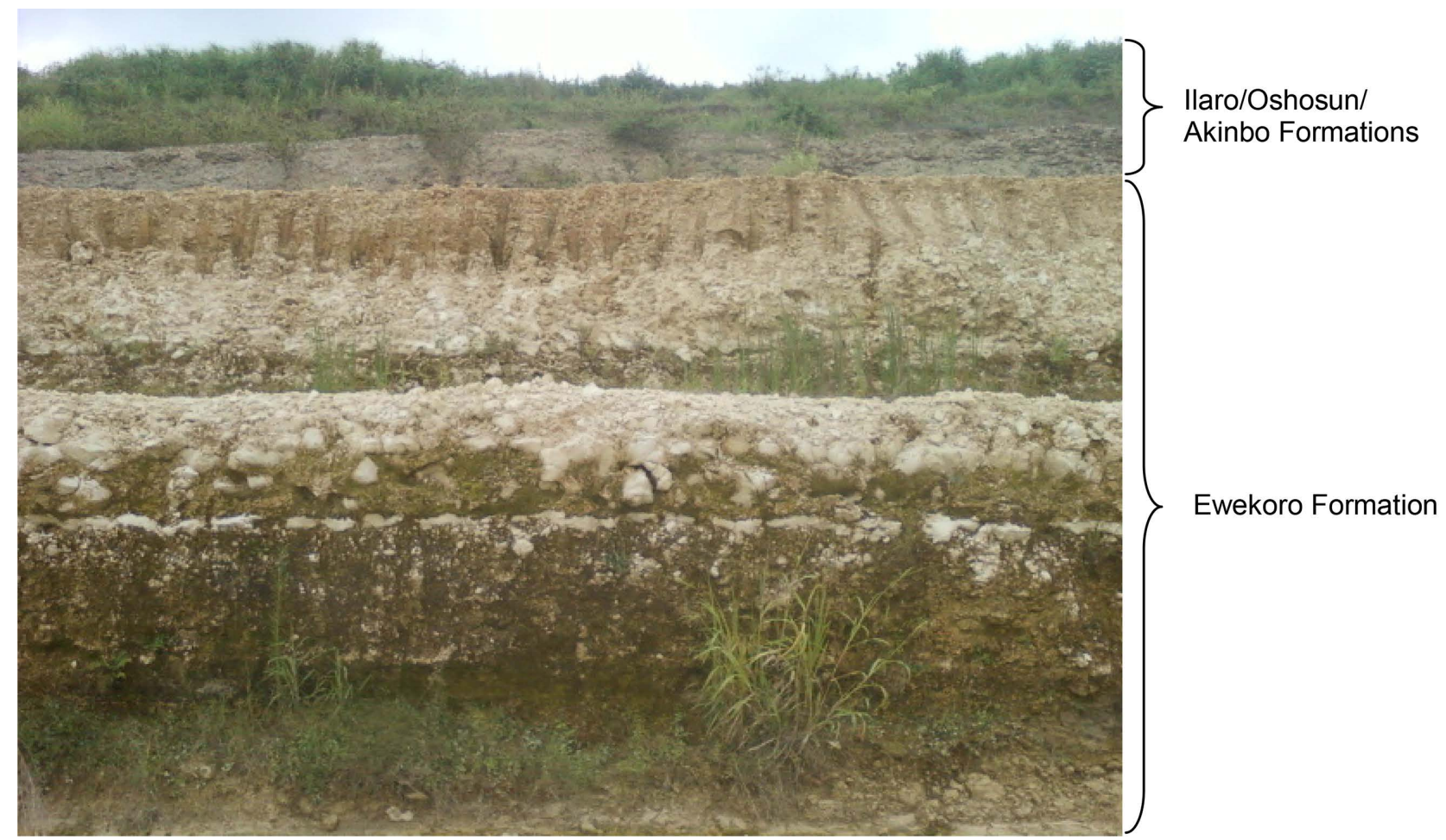

Figure 3. A lithostratigraphic section as exposed in Ibese. 
location 1

coordinates: $06^{\circ} 48^{\prime} 46.6^{\prime \prime}$

$03^{\circ} 7^{\prime} 55.32 "$

elevation: $50.55 \mathrm{~m}$

total depth: $18.50 \mathrm{~m}$

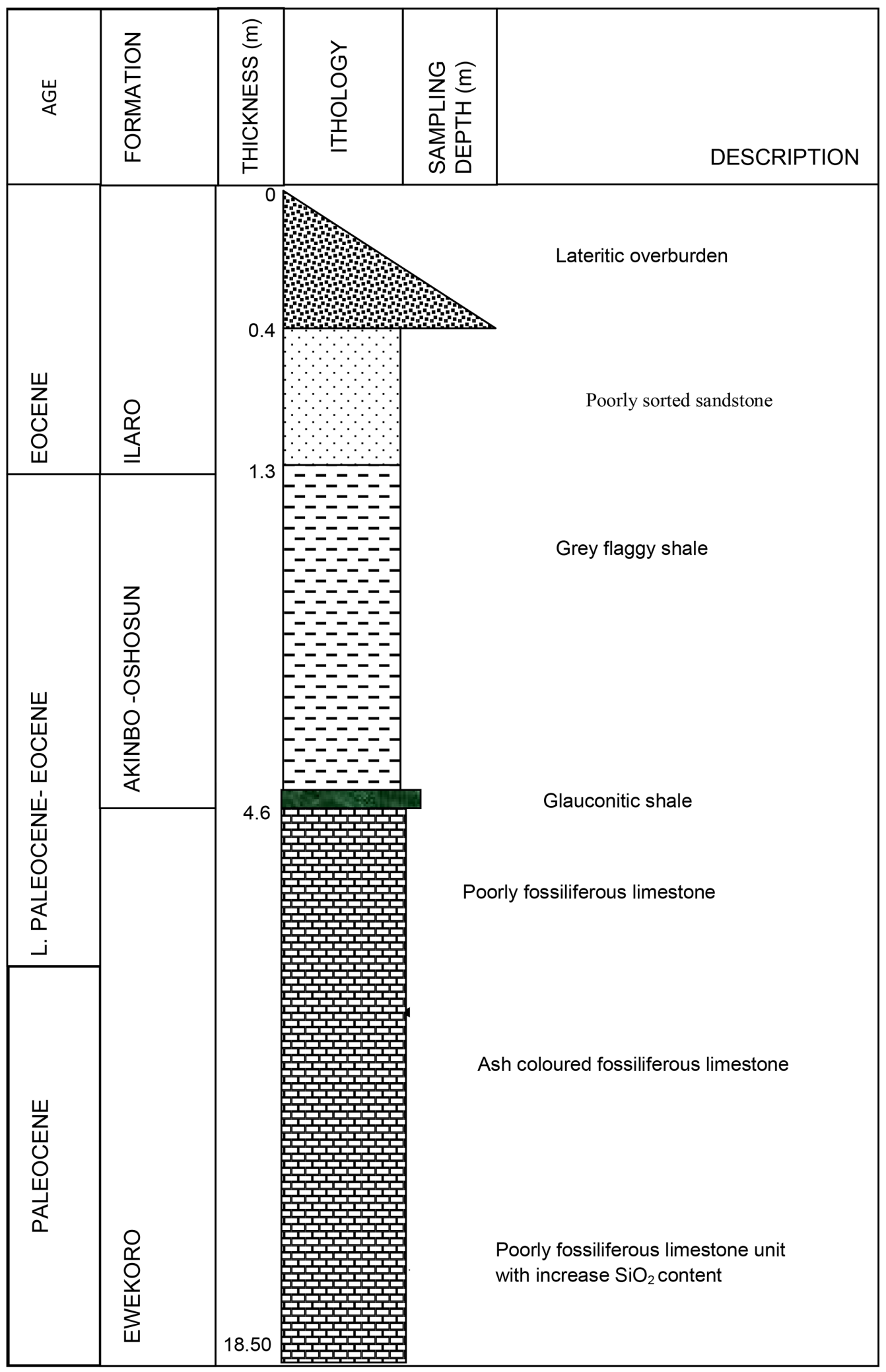

LEGEND

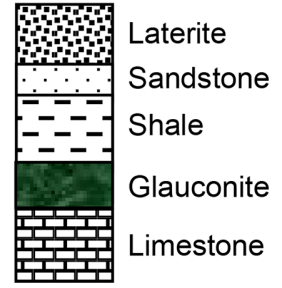

Figure 4. Lithostratigraphic profile of well-1. 


\section{Location 2}

Coordinates: $06^{\circ} 48^{\prime} 58.6^{\prime \prime}$

Elevation: $50.60 \mathrm{~m}$

$03^{\circ} 8^{\prime} 45.02^{\prime \prime}$

Total Depth: $20.50 \mathrm{~m}$

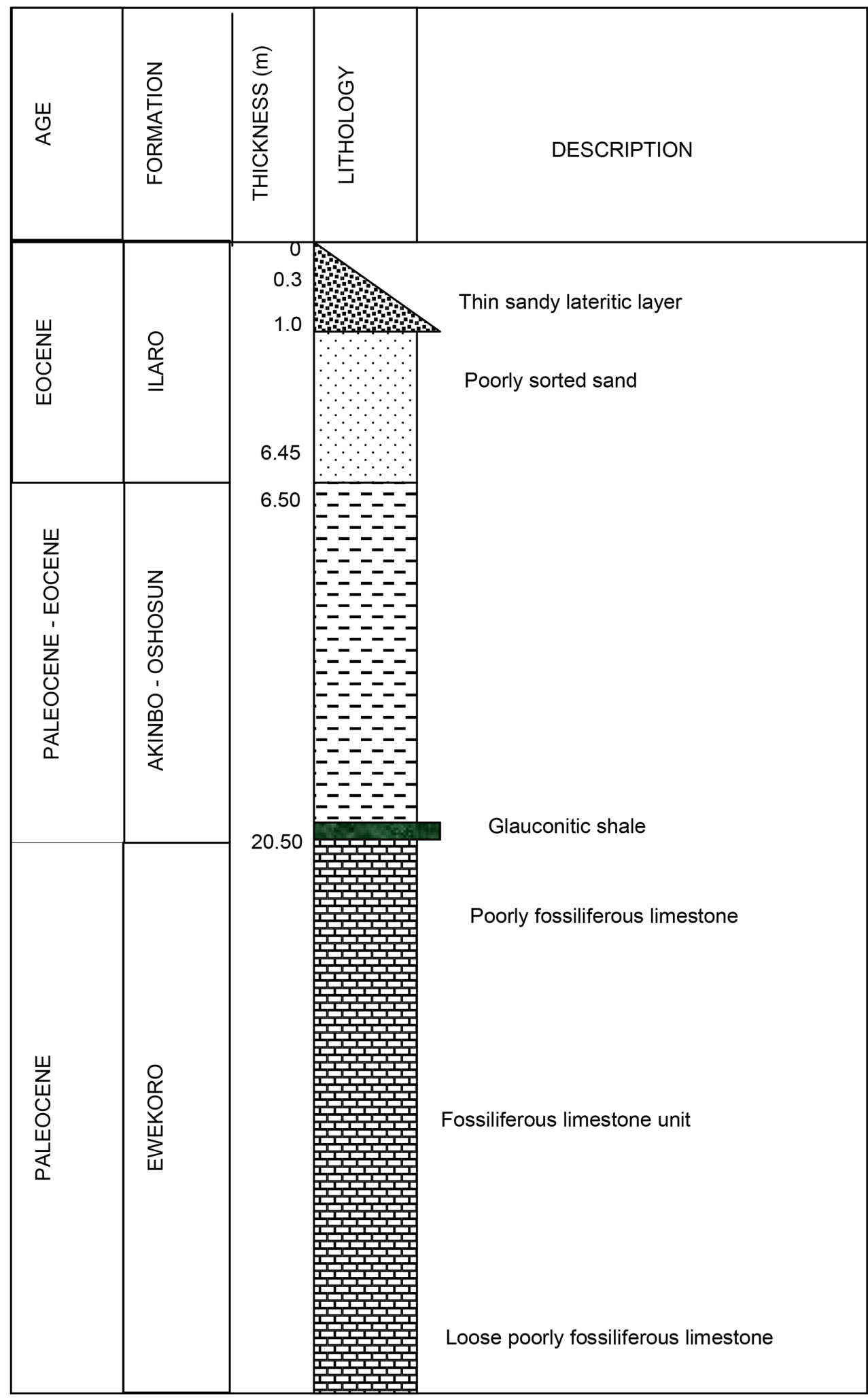

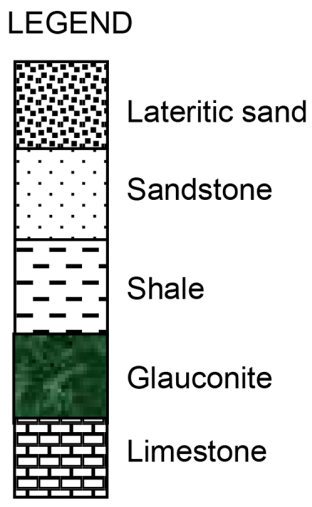

Figure 5. Lithostratigraphy profile of well-2. 
Location 3

Coordinates: $06^{\circ} 46^{\prime} 46.6^{\prime \prime}$

$03^{\circ} 11^{\prime} 27.32^{\prime \prime}$

Elevation: $50.24 \mathrm{~m}$

Total Depth: $18.50 \mathrm{~m}$

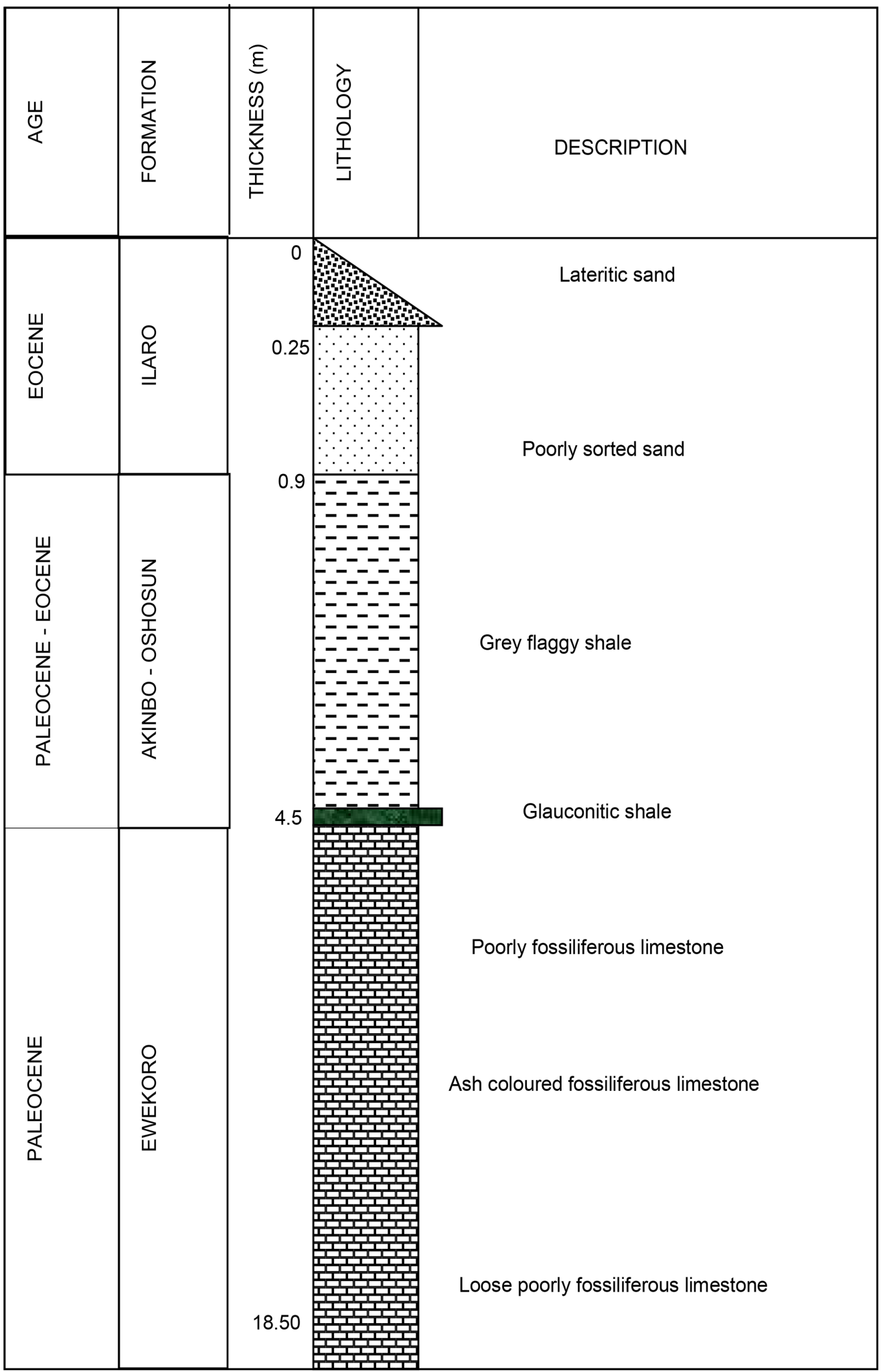

LEGEND

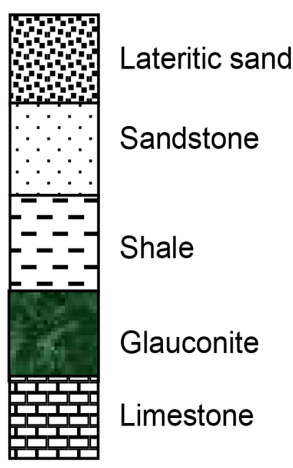

Figure 6. Lithostratigraphy profile of well-3. 
Location 4

Coordinates: $06^{\circ} 48^{\prime} 46.6^{\prime \prime}$

Elevation: $49.84 \mathrm{~m}$

$03^{\circ} 12^{\prime} 15.32^{\prime \prime}$

Total Depth: $5.0 \mathrm{~m}$

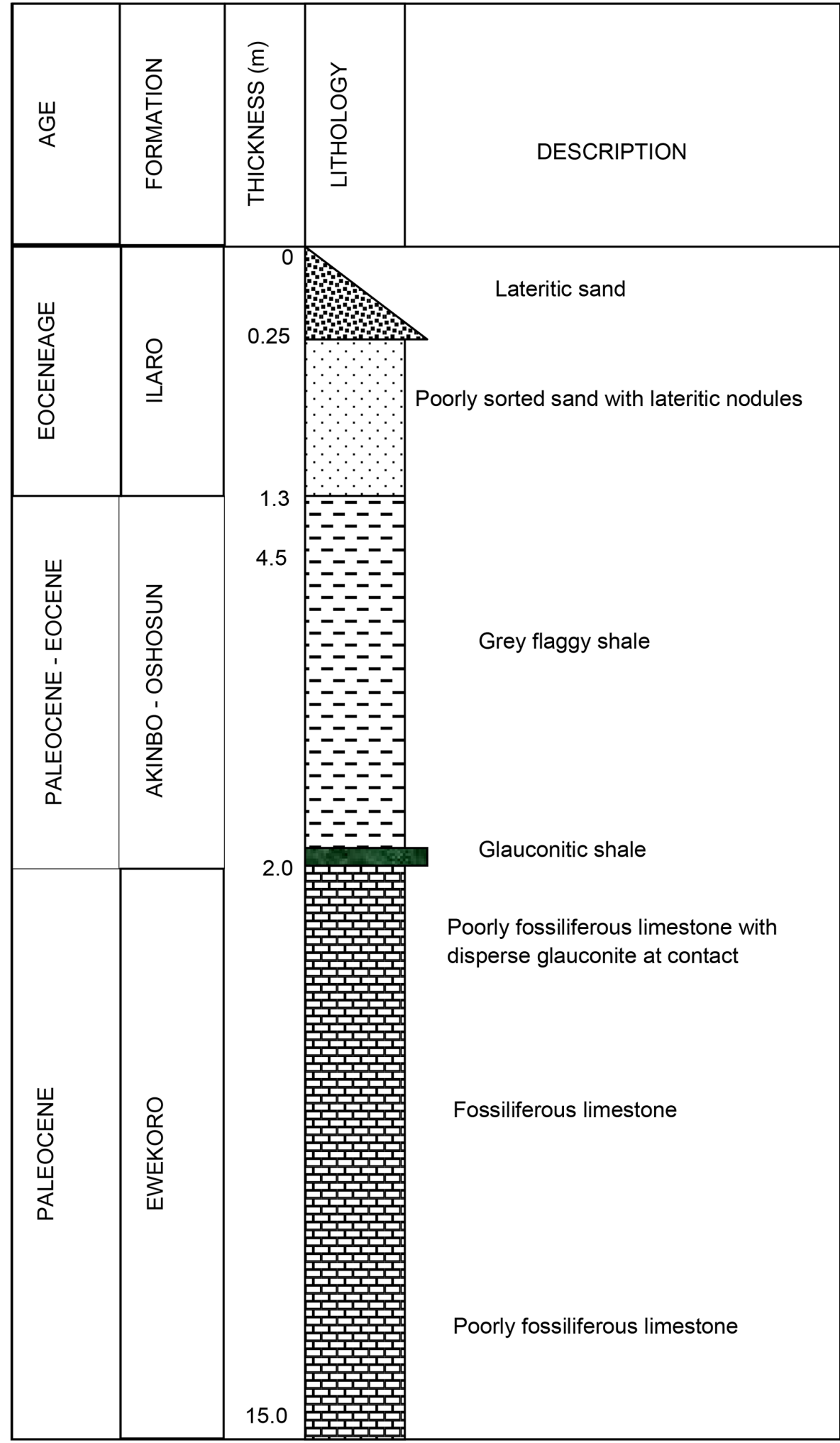

Sandstone

Shale

Glauconite

Limestone

Figure 7. Lithostratigraphy profile of well-4. 


\section{Location 5}

Coordinates: $06^{\circ} 48^{\prime} 46.6^{\prime \prime}$

$03^{\circ} 12^{\prime} 59.32^{\prime \prime}$

Elevation: $49.32 \mathrm{~m}$

Total Depth: $14.0 \mathrm{~m}$

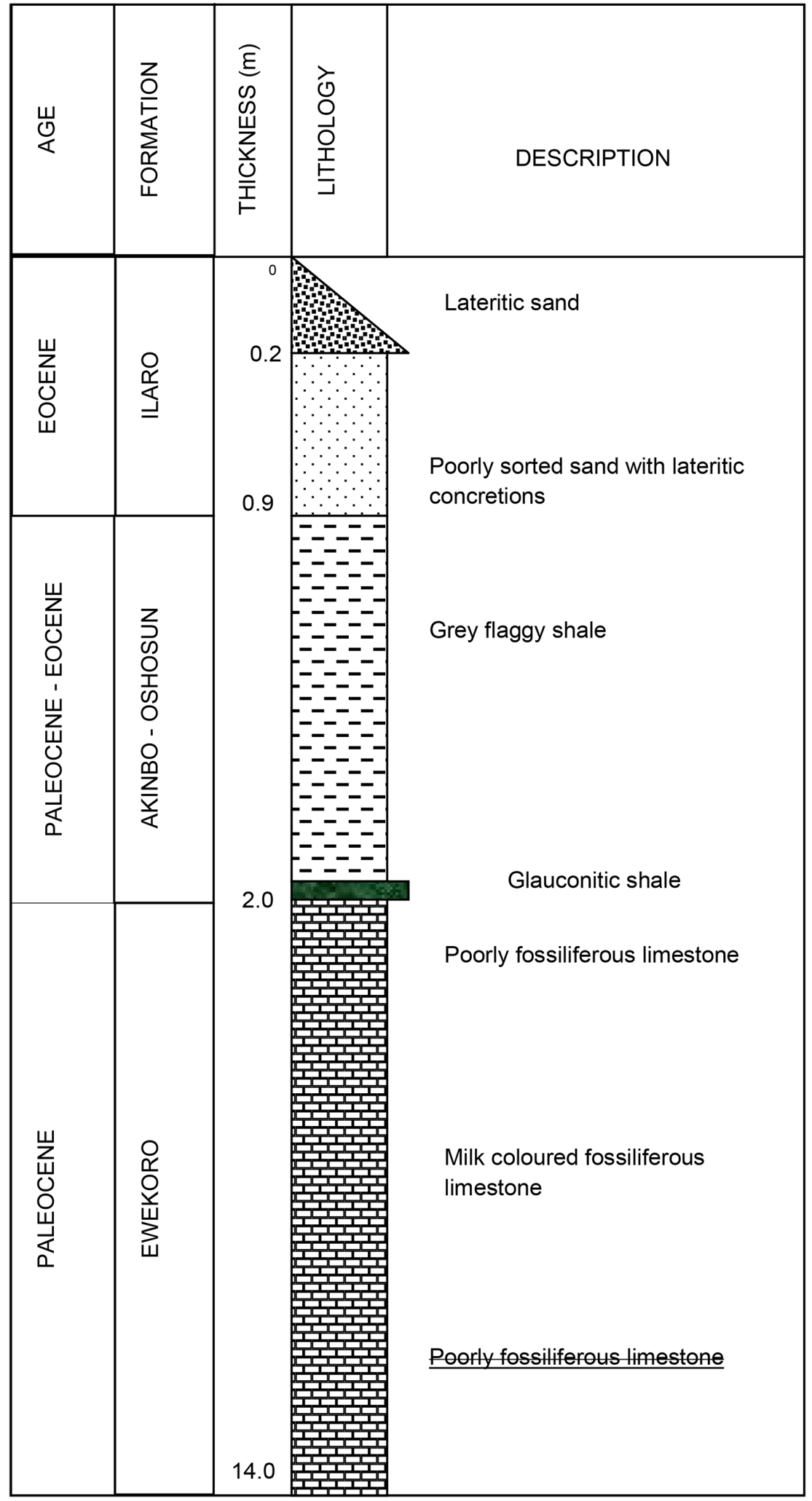

LEGEND

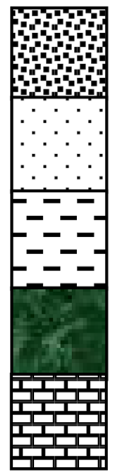

Lateritic sand

\section{Sandstone}

Shale

Glauconite

Limestone

Figure 8. A lithostratigraphic profile of well-5. 
Location 6

Coordinates: $06^{\circ} 49^{\prime} 04.6^{\prime \prime}$

Elevation: $50.60 \mathrm{~m}$

$03^{\circ} 13^{\prime} 47.12^{\prime \prime}$

Total Depth: $20.50 \mathrm{~m}$

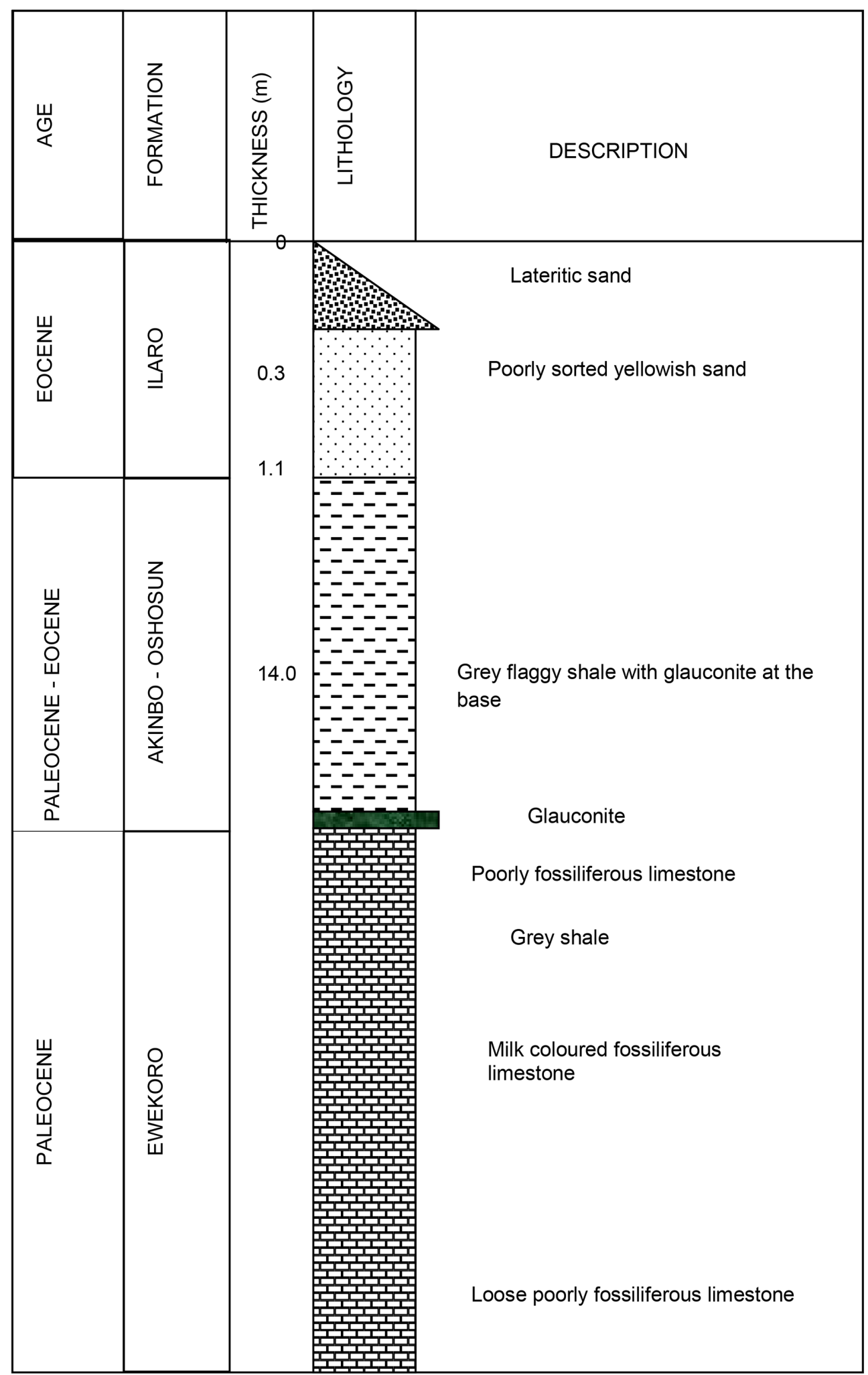

LEGEND

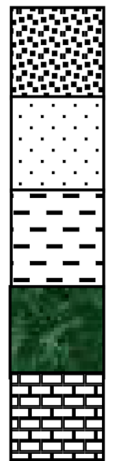

Lateritic sand

Sandstone

Shale

Glauconite

Limestone

Figure 9. Lithostratigraphy profile of well-6. 
significantly difference from the upper units. The clay and shale units are lateritized occurring as concretions ranging from brown to reddish brown and grey in colour respectively. The shale units are rich in glauconite and the limestone units constitute the weathered, poorly fossiliferous partly to the telltale of weathering on the layer and unweathered units which grades from the upper layer in a diffuse manner. The diagenetic process has had its toll on this layer due to pore spaces (mouldic and vuggy porosities) which shows casts of the disintegrated fossils (Figures 3-9). The marl units are described as the impure limestone. The deeper section of this unit shows contact between the basal weathered marl and a fresh top layer with the former occurring in the form of lateritic clay concretions.

\subsection{Geochemistry}

The major elements from the six wells within the Ewekoro Formation put the average percentages of major oxides across the wells as $\mathrm{CaO}(51 \%-56 \%), \mathrm{SiO}_{2}$ (2.6\% - 10.56\%), $\mathrm{Fe}_{2} \mathrm{O}_{3}(0.33 \%-0.94 \%), \mathrm{MgO}\left(0.78 \%-1.02 \%\right.$ and $\mathrm{Al}_{2} \mathrm{O}_{3}(0.72 \%-$ 0.98\%) (Appendix: Tables 1-6). The percentage concentration of $\mathrm{CaO}$ increases down the formation to approximately $13.0 \mathrm{~m}$ depth, where the highest value was recorded which tapper down the formation to the limestone-marl contact. The average percentage composition of $\mathrm{CaO}$ is $52.6 \%$ which indicate the dominancy of this oxide. This corroborate with the petrographic studies with the occurrence of carbonate bioclasts within the lime mud matrix [3] [19] [20]. The high ratio observed in calcium and magnesium defines a high calcite purity which is significance in the cement production. The presence of magnesium in carbonate rocks is a function of the temperature of deposition and time due to its removal by interstitial solution while dolomitization process could also contribute to high magnesium content [21].

The increase in the amount of $\mathrm{CaO}$ at different depths clearly defines diverse carbonate lithologic units. At $13 \mathrm{~m}$ depth, there is a significant increase in the amount of $\mathrm{MgO}$, this significant enrichment is attributed to increase in the amount of coralline algae and/or had an initial dolomitization where the water in the basin may be partially isolated under conditions of aridity and hence enriched in magnesium by continual inflow of sea water and subsequent precipitation of carbonate. Enrichment in this manner would form a heavy brine solution that moved down through porous sediments below and dolomitize those carbonates with which it came in contact with [21] [22] [23]. This depth of replacement serves as the datum of skeletal accumulations at water thermodynamic condition. At depth ranging from $12 \mathrm{~m}$ to about $14 \mathrm{~m}$, there is an increase in fossil content with large primary porosity which creates the avenue for replacement. At other deeper depths there is an inversion of aragonite to calcium and also consequent shedding of carbonate sediments from above [3].

The geochemistry of well- 1 defined the depth of carbonate diagenetic redistribution complemented by the amount of $\mathrm{SiO}_{2}$ measured from various horizons (Appendix: Table 2, Figure 10 and Figure 11). At $12 \mathrm{~m}$ to $14 \mathrm{~m}$ depth, 


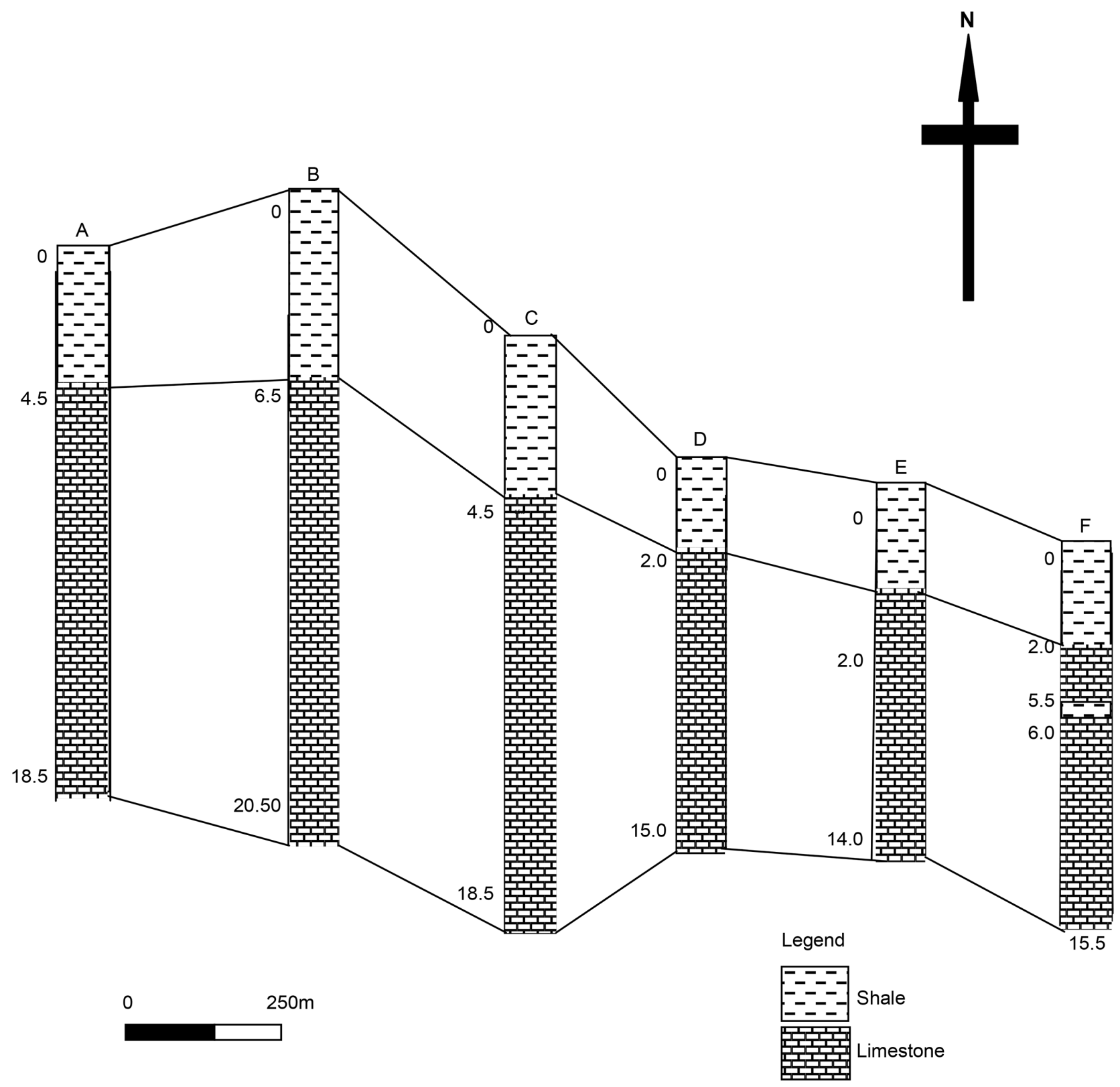

Figure 10. A lithofacies correlation of study wells showing diverse horizons.

MgO peaked showing the depth of favoured carbonate deposition and/or aragonite-calcite inversion which also correspond with the increase in the value of $\mathrm{SiO}_{2}$. This helps in inferring the environment of deposition and the diagenetic redistribution [21] [24]. Fairly high $\mathrm{SiO}_{2}$ percentage range between $2.4 \%$ to $10.38 \%$ (average of $4.363 \%$ ), suggest that the continental areas have an effect on the limestone though diagenesis and leaching tend to minmize such effects. Feldspars containing silica had been broken down during transportation before the commencement of diagenetic alterations. The presence of alumina $\left(\mathrm{Al}_{2} \mathrm{O}_{3}\right)$, confirms the occurrence of alumino silicates (feldspars) and micas in the adjacent areas that have being subjected to partial weathered prior diagenesis [3] [18] [22]. The average percentage composition of $\mathrm{Al}_{2} \mathrm{O}_{3}$ in the shale units (12.63\%) and 


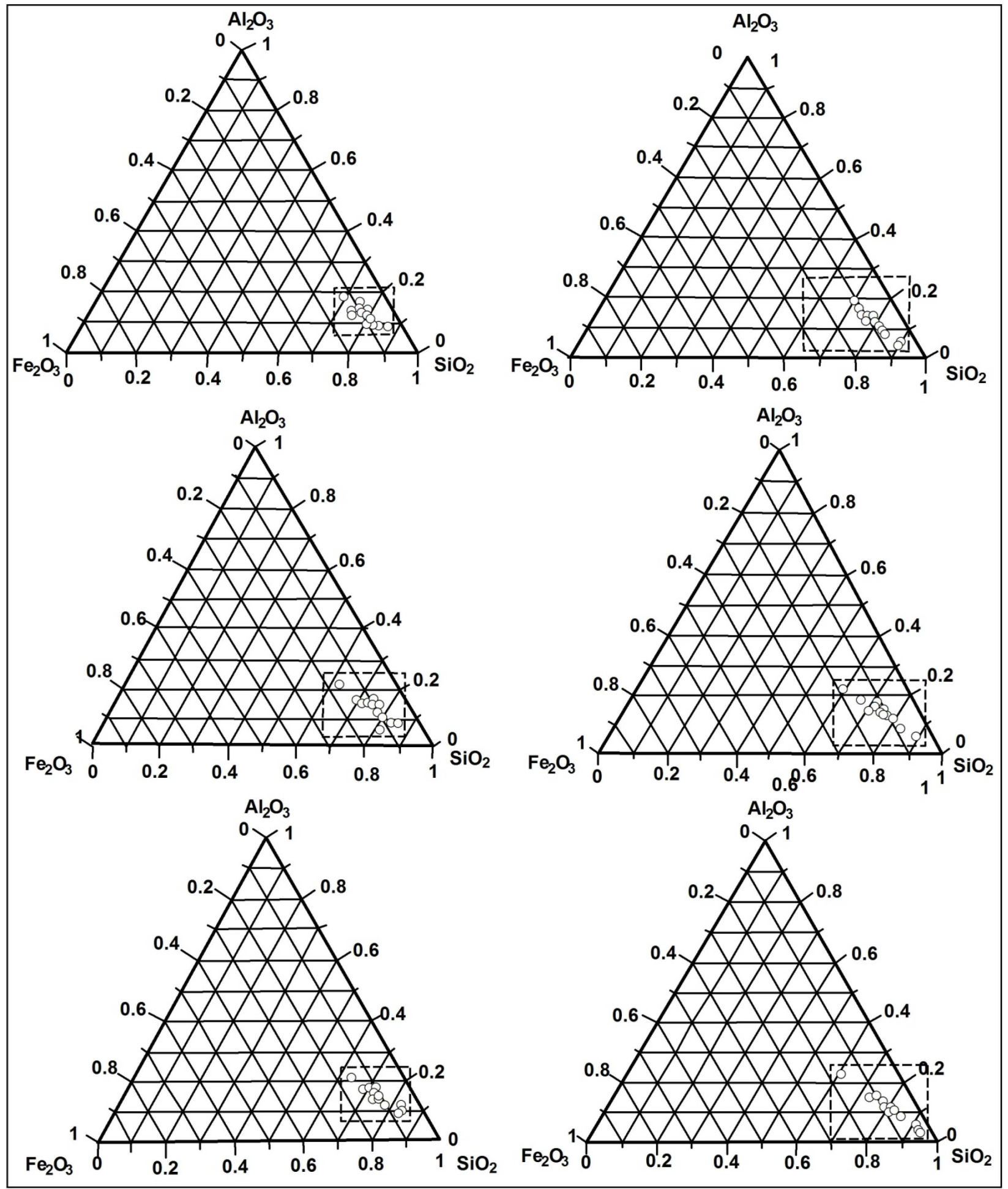

Figure 11. A Ternary plot showing degree of diagenesis in the study wells.

limestone $(0.693 \%)$ has constituted a slight alumina contaminant to the upper limestone units viametoric water percolation.

The modal composition of $\mathrm{Fe}_{2} \mathrm{O}_{3}$ in the Ewekoro Formation is low compared to other oxides in the well. The low $\mathrm{Fe}^{3+}$ confirms the suboxic character of the palaeoenvironment responsible for the deposition. The Fe/Mg ratios measured 
in the upper limestone horizon with an average of 0.40 is an indication of continental influence [22]. The moderate amount of both seems to reflect in the ferruginous syn-sedimentary and post depositional inputs of these sediments by surface meteoric waters flushing rapidly through ferromagnesian rich minerals (shale and glauconite) overlying the limestone. The rocks are stained at some parts with reddish brown colouration when exposed and it is seen that some of the allochems exhibit some iron oxide stained under the microscope [3]. However, the results have shown that the limestone sequence bounded by thick shales, correspond to higher value of $\mathrm{Fe} / \mathrm{Mg}$ ratio, due to the occurrence of shaley glauconitic bands and leaching of smectite clays into the unit. The result of the major oxides in well-2 has shown that the depth at which Mg occur in this well tend to become shallower to that measured in Well-1 suggesting the possible increase in water level thus causing the deposition of the carbonate at a shallower depth. The depth of $\mathrm{SiO}_{2}$ still remain at $13.5 \mathrm{~m}$ indicating a common diagenetic depth for both horizons. Silica percentage $\left(\mathrm{SiO}_{2}\right)$ is low and range between $2.4 \%$ to $10.38 \%$ (average of $4.46 \%$ ). This is an indication that the continental areas have a mild effect on the limestone through diagenesis [21]. The presence of alumina with average value of $14.43 \%$ (shale) and $0.66 \%$ (limestone) confirms the presence of little alumino silicates in the adjacent areas that had not been completely weathered prior diagenesis and also that which dripped on the upper limestone horizons with high alumina value of $2.44 \%$ in the limestone [21]. The modal composition of $\mathrm{Fe}_{2} \mathrm{O}_{3}$ is low relative to others hence suggesting low availability of oxygen to oxidize $\mathrm{Fe}^{2+}$ present in heavy minerals to $\mathrm{Fe}^{3+}$ during diagenesis with little effect of post depositional processes on the overlying glauconite (Appendix: Table 2, Figure 11 and Figure 12).

The amount of $\mathrm{MgO}$ relative to depth in well-3 defined the depth of carbonate primary replacement complemented by the amount of $\mathrm{SiO}_{2}$ measured from various horizons which showed different peaks (Figure 11). Though there exists fluctuations at diverse horizons but the depth of high $\mathrm{MgO}$ and $\mathrm{SiO}_{2}$ concentration is put at $12.0 \mathrm{~m}$ to $14.0 \mathrm{~m}$. MgO peaked showing the depth of favoured carbonate deposition of aragonite - calcite inversion which also correspond with an increase in the amount of $\mathrm{SiO}_{2}$. Two peaks were recorded for this horizon (Figure 11). An average of $64.91 \%$ and $4.89 \%$ were measured for the shale and limestone respectively. Relative to previous wells, a high percentage of $\mathrm{SiO}_{2}$ was recorded at $13.0 \mathrm{~m}$ depth which indicate the presence of authigenic quartz and minor detrital quartz [21] (Appendix: Table 3). An average of 11.97\% and 0.96\% of alumina were recorded for the shale and limestone. A local enrichment of $4.2 \%$ was measured at the upper limestone horizons while a gradual decrease in $\mathrm{Al}_{2} \mathrm{O}_{3}$ with depth was recorded. This indicated the rate of $\mathrm{Al}_{2} \mathrm{O}_{3}$ percolating into the limestone from the shale unit. The $\mathrm{K}_{2} \mathrm{O}$ value $(0.06 \%)$ measured from the top of the limestone unit confirm with the shaly contamination. Average values of $\mathrm{Fe}_{2} \mathrm{O}_{3}(7.864 \%$ and $0.675 \%)$ were recorded for the shale and limestone while a peak of $8.36 \%$ at the shale-limestone contact suggest the partial oxidation of glauconite from $\mathrm{Fe}^{2+}$ to $\mathrm{Fe}^{3+}$. 

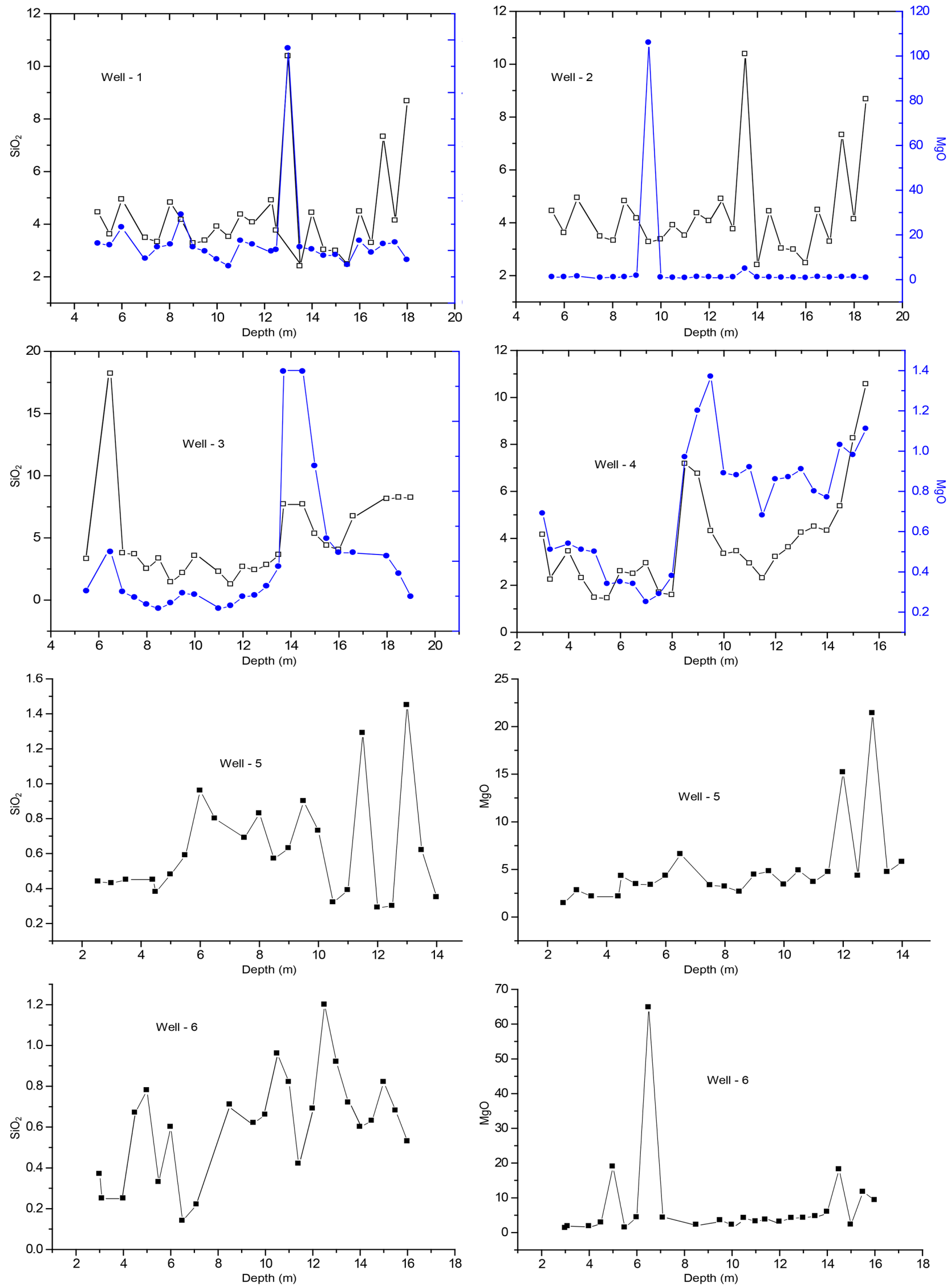

Figure 12. Plots of $\mathrm{MgO}$ and $\mathrm{SiO}_{2}$ percentage against depth for the study wells. 
The ratio of $\mathrm{MgO}$ with depth in well-4 defined the depth of carbonate diagenetic re-distribution which is complemented by the amount of $\mathrm{SiO}_{2}$ measured from various horizons with different peak (Figure 10). At $12 \mathrm{~m}$ to $14 \mathrm{~m}$ depth $\mathrm{MgO}$ peaked showing the depth of favoured carbonate deposition or aragonite-calcite inversion which also correspond with an increase in the amount of $\mathrm{SiO}_{2} . \mathrm{SiO}_{2}$ percentage is fairly high and ranged from $1.45 \%$ to $10.56 \%$ (average of $3.87 \%)$. The rock can be described as chemically pure indicating that the continental areas have little effect on the limestone [24] (Appendix: Table 4). Feldspar containing silica had been weathered during transportation prior the commencement of diagenesis. The values of $\mathrm{Al}_{2} \mathrm{O}_{3}$ in the shale $(11.8 \%)$ and limestone $(0.81 \%)$ lithofacies confirms the presence of little alumino silicates in the adjacent areas that are partially weathered priorthe diagenetic processes in the overlying shale facie. Significant shale contamination is well defined by the increase in percentage of $\mathrm{K}_{2} \mathrm{O}(0.11 \%)$ measured at the shale-limestone contact [21]. The percentage composition of $\mathrm{Fe}_{2} \mathrm{O}_{3}$ measured in the shale (7.3\%) increased compared to other oxides thus helps to infer the amount of oxygen available to oxidize $\mathrm{Fe}^{2+}$ present in heavy minerals to $\mathrm{Fe}^{3+}$. The increase in the amount of $\mathrm{Fe}_{2} \mathrm{O}_{3}$ in this horizon describes the intense chemical weathering of the continental areas (Appendix: Table 4).

In well-5 at $13.0 \mathrm{~m}$ depth, there is a sharp increase in both $\mathrm{MgO}$ and $\mathrm{SiO}_{2}$ (Figure 12). This graphical behaviour is suggestive of an increase in the thickness of the deposit towards the continent, which showed a decrease in the extent of continental inputs as the deposits progrades onshore. Silica $\left(\mathrm{SiO}_{2}\right)$ percentage ranged from $1.4 \%$ to $10.2 \%$ (average of $5.1 \%$ ) (Appendix: Table 5). This is an indication of the Continental areas having little effect on the limestone [22]. Alumina, $\left(\mathrm{Al}_{2} \mathrm{O}_{3}\right)$, increases in this horizon confirms the presence of alumino-sili- cates in the adjacent formations. The effect of shale contaminante in the limestone units is minimal. This corroborates with the average percentage of $\mathrm{K}_{2} \mathrm{O}(0.1 \%)$. The amounts of Fe decreases down the formation making it obvious that it is post depositional. This is due to the percolation of meteoric waters through shale and glauconitic layers into the underlying limestone units.

\subsection{Carbonate Petrography}

Three microfacies recognized are shelly biomicrite (bioclastic wackestone), shelly biosparmicrite (bioclastic wackestone-packstone) and alga biosparmicrite (Alga bioclastic wackestone-packestone) [21] [22] [25] (Appendix: Table 7 and Figures 13-15).

\subsubsection{Shelly Biomicrite}

This represents the topmost portion of the limestone layers. The rock is micrite (mud) supported and contain a substantial amount of bioclasts (grain). At different sections, the rock defines about $1 / 4$ of spar. Bioclasts described from this layer include pelecypods which take a higher percentage of bioclasts population, gastropods, echinoids, cup corals exhibiting radial structure and coralline algae. 

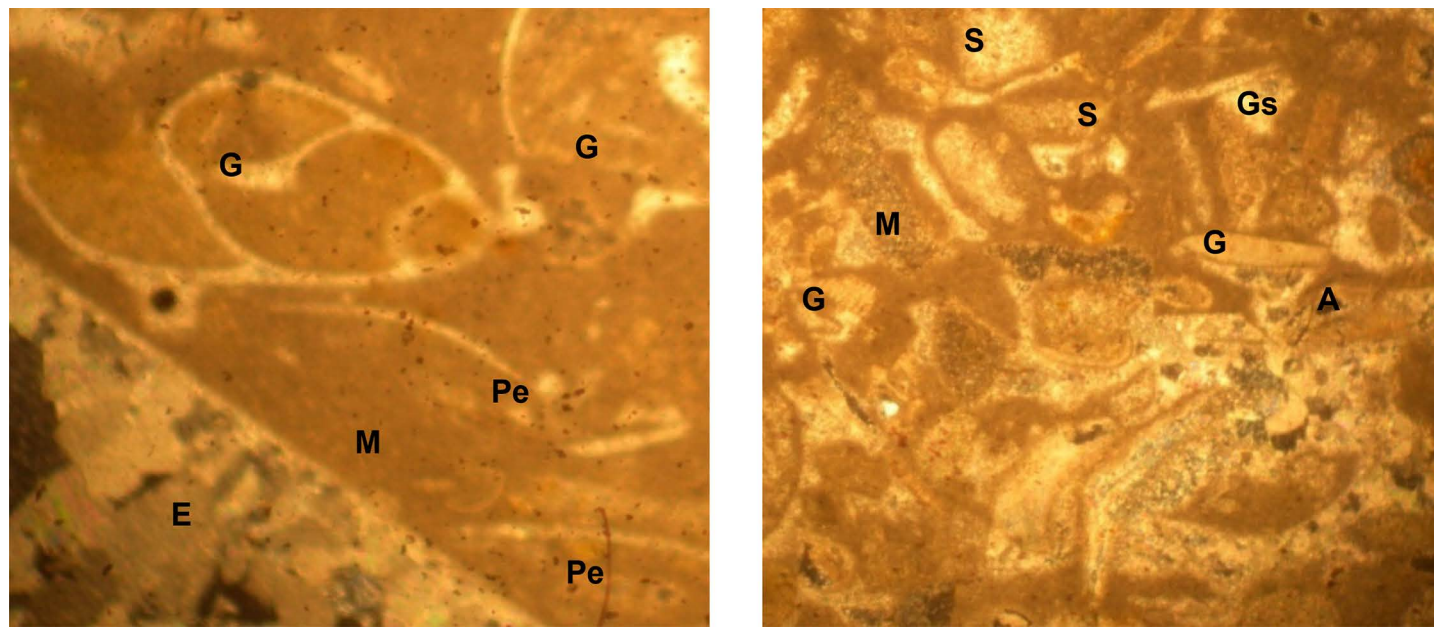

(a)
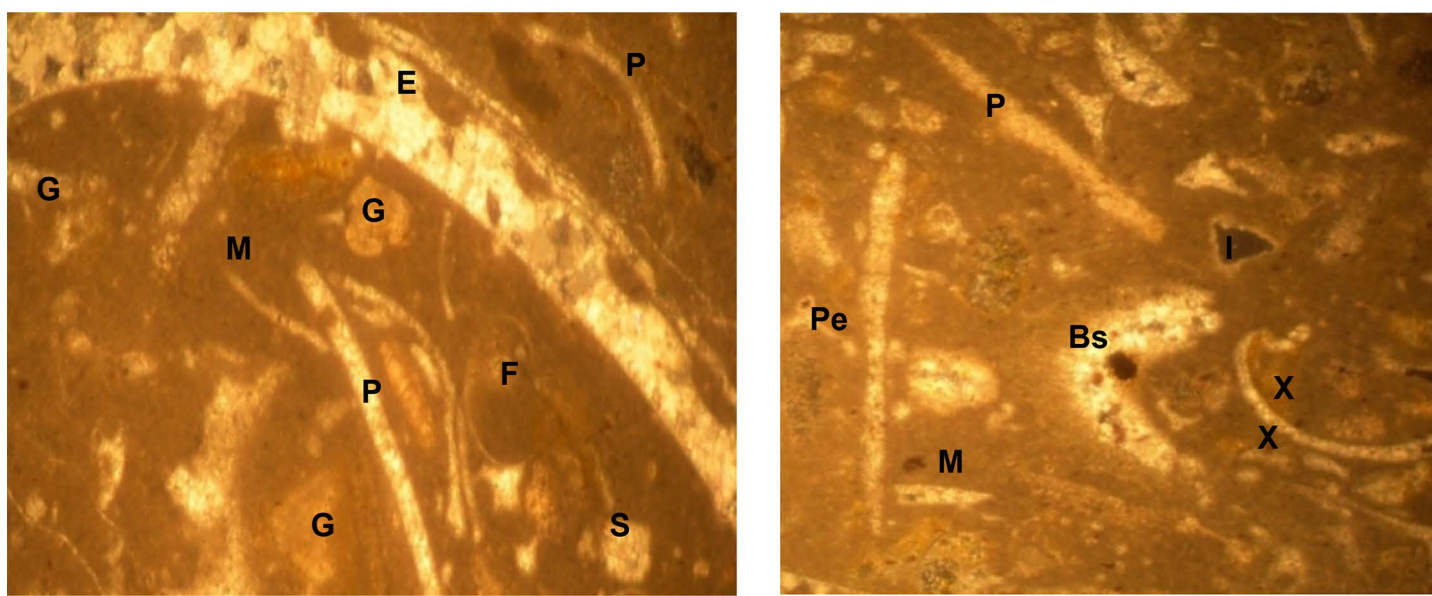

(b)

Figure 13. (a): Photomicrographs of a shelly biomicrite (Sample A1). Allochems present include mollusk which are gastropod $(\mathrm{G})$ pelecypod $(\mathrm{Pe})$, spar ite $(\mathrm{S})$. Note the internal micritization of the fossils especially the mollusk, brachiopod and pelecypod. (Mag. X40). (b): Photomicrographs of shelly biomicrite. The allochems present include echinoid (E) pelecypods $(\mathrm{P})$, foraminifera $(\mathrm{F})$, broken shell fragment $(\mathrm{X})$, prismatic pelecypod, spar fill brachiopod (Bs), gastropods $(\mathrm{G})$ and micrite $(\mathrm{M})$, sparite $(\mathrm{S})$. Note the internal micritization of the fossils and spar fill echinoid. (Mag. X40).

Internal micritization of some grains were observed especially the mollusks, gastropods, echinoids and brachiopods. Micritic corrosion of the surface of coralline algae and pelecypods gave rise to more degenerated structures. Internal recrystallization of bioclasts is well defined. Non bioclastic components are intraclasts, quartz grains and occasional pellets.

\subsubsection{Shelly Biosparmicrite}

This microfacies succeeds the top biomicrite due to the increase in intraclasts, spar and bioclasts populations. It clearly define the increase in population of coralline and rod-like algae compared to others while there is an increase in population of prismatic mollusks, intraclasts shell fragments and cup algae. It shows sorting and compaction relative to the first microfacies and a decrease in internal structure of bioclasts. Internal sparitization increases in this facies while the 

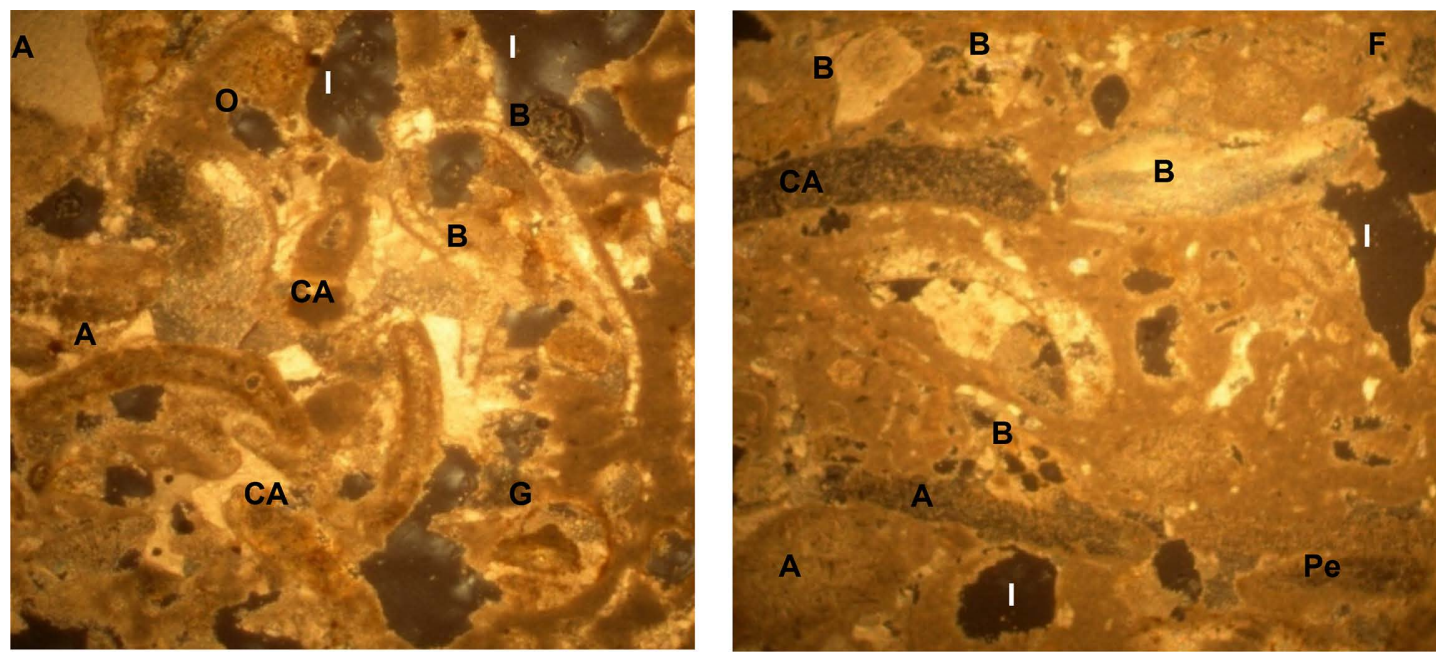

(a)
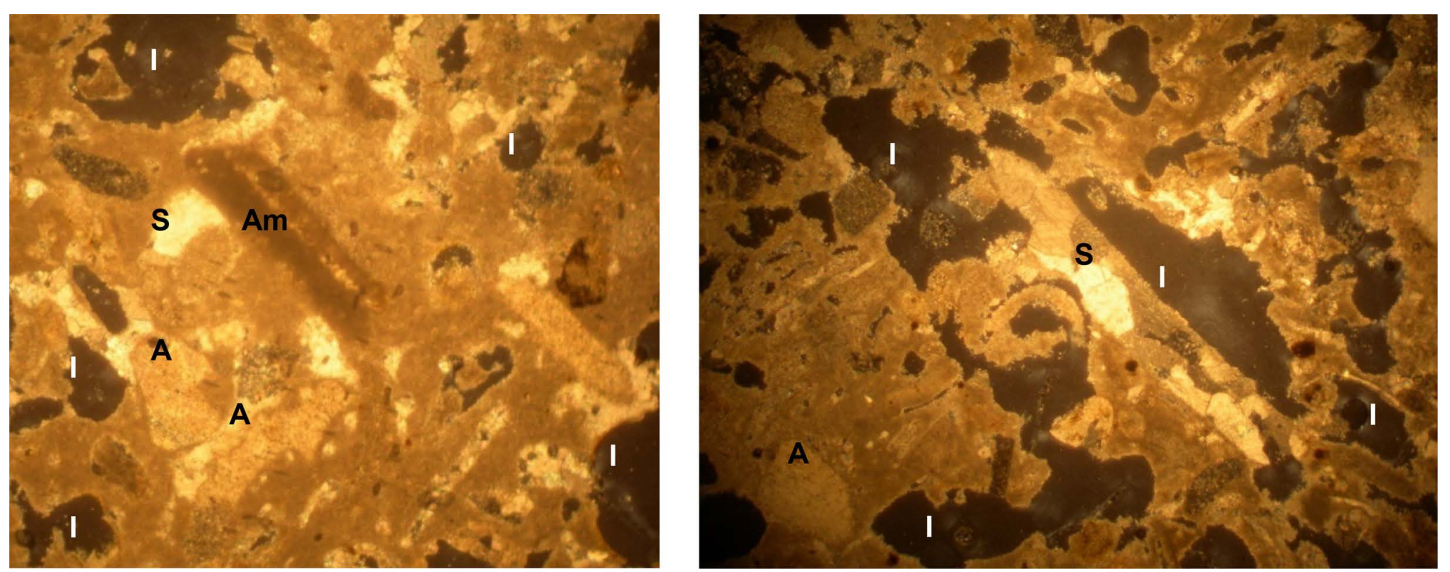

(b)

Figure 14. (a): Photomicrographs of sorted shelly biosparmicrite (Sample B2). Allochems present include coralline algae (CA), intraclasts $(\mathrm{I})$, ooids $(\mathrm{O})$, brachiopods $(\mathrm{B})$, pelecypods $(\mathrm{Pe})$, foraminifera $(\mathrm{F})$, algae $(\mathrm{A})$. Note the spar cement around coralline algae and brachiopods and internal micritization of the bioclasts. (Mag. X40). (b): A photomicrographs of shelly biosparmicrite. The allochems present include micritizedalgae (Am), algae (A), intraclasts (I), sparite (S). Note the predominance of internal micritization of thebioclasts and also the binding action of sparite within the lime mud. (Mag. X40).

spars crystal increase outward from shell boundaries, however, the compaction increases grain to grain contact.

\subsubsection{Alga Biosparmicrite}

This microfacies is the lowermost section of the limestone sequence in Ibese. It is synonymous to the alga bioclastic wackestone-packstone [25]. This facies is characterized by abundant stromatolitic algae which defines sediment binding. Other bioclasts include coiled gastropods, micritized echinoids, foraminifera, mollusks and spherulitic corals. Non bioclastic components include pellets and intraclasts which make about $1 / 3$ of various portions of this microfacies. The radial pattern show internal rim cement (microspore calcite cement) within micritic ground mass. Other depositional texture that can be inferred from this layer is oncolitic grainstone defined by corals and algae complemented by increase 

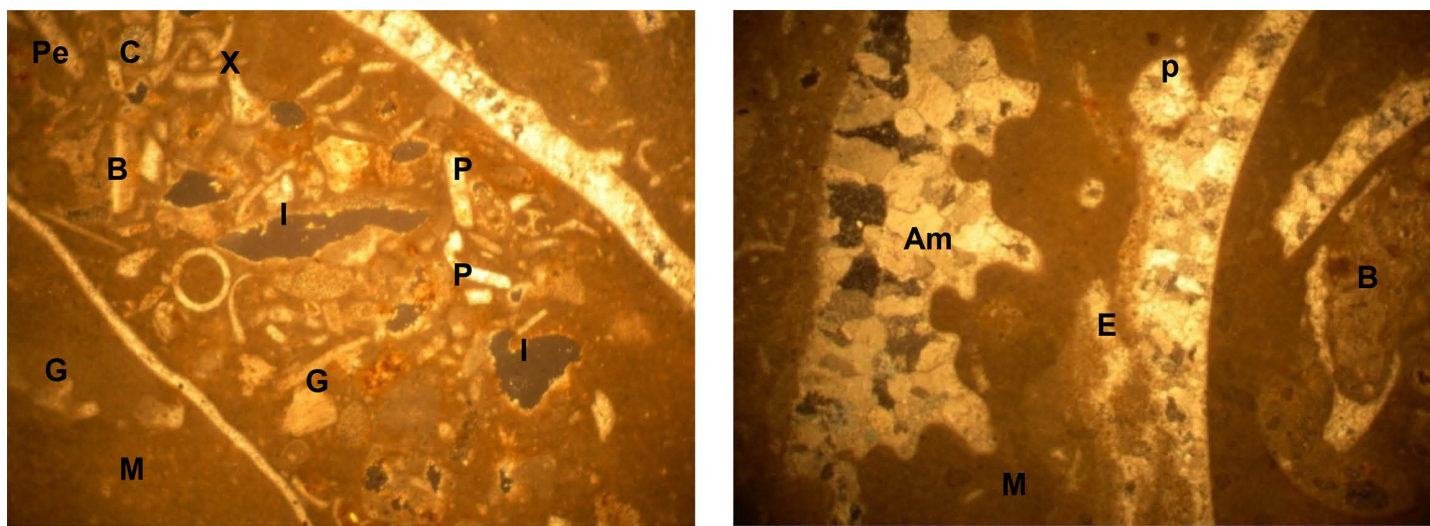

(a)
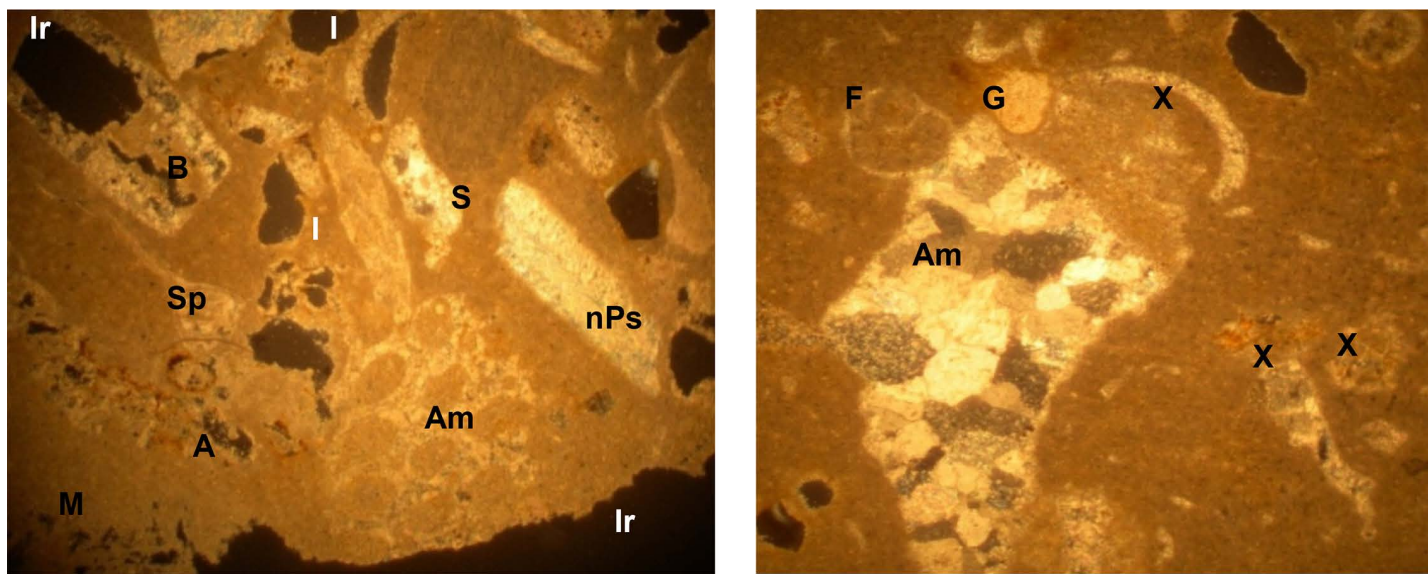

(b)

Figure 15. (a): Photomicrographs of alga biosparmicrite (Sample C2). The allochems present include brachiopod (B), pelecypods $(\mathrm{Pe})$, intraclasts $(\mathrm{I})$, gastropods $(\mathrm{G})$, pellets $(\mathrm{P})$ coralline algae $(\mathrm{C})$. alga mat (Am). Note the internal micritization and sparitization and its binding action on the bioclasts and iron mineral infill. (Mag. $X 40$ ). (b): Photomicrographs of alga biosparmicrite. The allochems present include Brachiopod (B), Sponges (Sp), intraclasts (I) sparitized nacreous pelecypod (nPs). Notice the internal micritization of the fossils and Iron mineral (Ir) infill also note the growth sparry calcite within the alga mat and also the rarity of micrite within the mat. (Mag. X40).

in the amount of skeletal debris. Grain dissolution and interparticle porosity are significant as they reflect the degree of diagenetic process, hence affecting their physical properties.

\subsection{Depositional Palaeoenvironment}

Based on the sedimentological indices, the shale units of Akinbo Formation are fine with no sand, silt or carbonates, grey, flaggy and slabby indicating low energy quiet water setting. The palaeobathymetry of the fossil assemblage defined from the earlier studies indicated benthic dwellers except for some shell fragments whose origin could not be ascertain [3] [20] [22] [26].

As the processes of micritization and sparitization are diagenetic processes which may involve the recrystallization of solid solutions of carbonate into coarse calcitic crystals or the mechanical degradation of shells into carbonate mud which may eventually alter the initial depositional fabric of the deposit, se- 
quel to this, there has been decrease in the total porosity of the rocks where the topmost biomicrite defines mouldic, fenestrael, intraparticle and little interparticle porosities. The shelly biosparmicrite and alga biosparmicrite microfacies are characterized by increase in grains' components which increase the grain to grain contacts of the rock units thus enhances interparticle porosity [27].

The magnesium content of the carbonate rock is low when compared to calcium, while the average percentage composition across the wells ranges between $0.78 \%-1.02 \%$. This low composition is attributed to an increase in organism complexities (advanced phyla) based on this premise, a shallow marine environment of deposition is suggested. The presence of $\mathrm{SiO}_{2}, \mathrm{~K}_{2} \mathrm{O}$ and $\mathrm{Al}_{2} \mathrm{O}_{3}$ is an indication of clastic input and degree of diagenesis on the lithofacies [21] [22] [28]. The downhole increment of $\mathrm{SiO}_{2}$ in the formation indicates an increase in the continental influence. In well-1, the relative increase in the amount of $\mathrm{SiO}_{2}$ defines the degree of continental influence which suggest that the paleobathymetry during the formation of the carbonate to be within the range of $12.0 \mathrm{~m}$ to $14.0 \mathrm{~m}$ depth suggesting a shallow water environment (Figure 10 and Figure 11). The average $\mathrm{Fe} / \mathrm{Mg}$ in well-3 measured in the limestone (1.24) indicated gradual increase suggesting a continental influence. The moderate amount of both reflect the ferruginous syn-sedimentary and post-depositional inputs of these sediments by suface meteoric waters flushing rapidly through ferromagnesian rich minerals overlying the limestone.

\section{Conclusion}

Detailed mapping and logging of the study area showed the total thickness of the limestone ranged from $12.0 \mathrm{~m}$ to $15.0 \mathrm{~m}$. The limestone consists of milky to grey and nodular to massive fossiliferous units. It is evident that the sand units increase with depth. The major element percentages revealed an increase in $\mathrm{CaO}$ with depth and an average of $56 \%$ and also a corresponding increase in $\mathrm{MgO}$ with average of $0.86 \%$ which show the calcitic nature of the deposit. The six wells showed significant peaks in $\mathrm{MgO}$ and $\mathrm{SiO}_{2}$ at depth approximately $13.0 \mathrm{~m}$. The increase in the $\mathrm{Mg}$ component suggests diagenetic processes and the significant occurrence of $\mathrm{Al}_{2} \mathrm{O}_{3}$ and $\mathrm{Fe}_{2} \mathrm{O}_{3}$ in the sequence is an indication of continental influence in the diagenetic history of the sedimentation. Three different microfacies were recognized based on depositional texture, they are shelly biomicrite, shelly biosparmicrite and alga biosparmicrite. The predominance of micrite as the cementing matrix revealed that the rock was deposited in a quiet shallow inner shelf environment occasioned by storm waves. The elemental composition of the rock units suggested the suitability of deposit for cement production however; further studies could look into the lime saturation factor (LSF), silica modulus (SR) and alumina modulus (AR) in making up for corrections to meet production specifications.

\section{References}

[1] Whiteman, A.J. (1982) Nigeria, Its Petroleum Geology, Resources and Potential. 
Graham and Trotman Publishing, London, 1 and 2, 251-269, 104-110. https://doi.org/10.1007/978-94-009-7361-9

[2] Nton, M.E., Tijani, M.N. and Ikhane, P.R. (2009) Aspect of Rock-Eval Studies of the Maastrichtian-Eocene Sediments from Subsurface, in the Eastern Dahomey Basin Southwestern Nigeria. European Journal of Scientific Research, 25., 417-423.

[3] Boboye, O.A. and Raji, K.A. (2013) Aspect of Biostratigraphic and Petrographic Studies of the Late Palaeocene to Eocene Sequence of the Eastern Dahomey Embayment, Southwestern Nigeria. Journal of Science Research, 12, 231-262.

[4] Akinmosin, A. and Osinowo, O.O, (2010) Petrographical Study of Ewekoro Carbonate Rocks, in Ibese, South Western Nigeria. Earth Sciences Research Journal, 14, 187-196.

[5] Adekeye, O.A. and Akande, S.O. (2006) Depositional Environment and Reservoir Potential Assessment of the Paleocene Ewekoro Formation, eastern Dahomey Basin South-Western Nigeria in Nigeria. Journal of Mining and Geology, 42, 133-140.

[6] Omatsola, M.E. and Adegoke, O.S. (1981) Tectonic Evolution and Cretaceous Stratigraphy of the Dahomey Basin. Journal of Mining Geology, 18, 130-137.

[7] Ogbe, F.A. (1972) Stratigraphy of Strata Exposed in the Ewekoro Quarry Southwestern Nigeria. African Geology, 305-322.

[8] Adekeye, O.A. and Akande, S.O. (2010) The Principal Source Rocks for Petroleum Generation in the Dahomey Basin, Southwestern Nigeria. Continental Journal of Earth Sciences, 5, 42-55.

[9] Boboye, O.A. and Nwosu, O.R. (2013) Petrography and Geochemical Indices of the Lagos Lagoon Coastal Sediments, Dahomey Basin (Southwestern Nigeria) Sea Level Change Implications. Quaternary International Journal, 338, 14-27.

https://doi.org/10.1016/j.quaint.2013.07.006

[10] Ekweozor, C.M. (1990) Geochemistry of Oil Sands of Southern Nigeria. Mining and Geosciences Society Publications on tar Sands Workshop. Ago Iwoye, 50-62.

[11] Nwanchukwu, J.I., Adegoke, O.S. and Salami, M.B. (1992) Micropaleontology of the Upper Cretaceous and lower Tertiary of Bodashe-1 and Ile Paw Wells Southwestern Nigeria. Journal of Mining and Geology, 29, 163-170.

[12] Ikhane, P.R., Akintola, A.I., Akintola, G.O., Okunlola, O.A. and Oyebolu, O.O. (2013) Granulometric Analysis and Heavy Mineral Studies of the Sandstone Facies Exposed near Igbile, South Western Nigeria. International Research Journal of Geology and Mining (IRJGM), 3, 158-178.

[13] Adeonipekun, P.A., Ehinola, O.A., Yussuph, I.A., Toluhi, A. and Oyelami, A. (2012) Bio-Sequence Stratigraphy of Shagamu Quarry Outcrop, Benin Basin, Southwestern Nigeria. World Applied Sciences Journal, 18, 91-106.

[14] Fakolade, O.R. and Obasi, R.A. (2012) The Geotechemical Assessment of Subsurface Coastal Plain Clastic Deposits of Eastern Dahomey Basin around Lagos Area, South West Nigeria. International Journal of Science and Technology, 1, 300-307

[15] Abayomi, E. and Dare, O.O. (2016) Geochemical Evaluation of Arimogija-Okeluse Limestones, Eastern Dahomey Basin, Southwestern Nigeria. Journal of Sedimentary Petrology, 36, 317-340. https://doi.org/10.18052/www.scipress.com/ilns.56.57

[16] Ehinola, O.A., Oluwajana, A. and Nwabueze, C.O. (2012) Depositional Environment, Geophysical Mapping and Reserve Estimation of Limestone Deposit in Arimogija-Okeluse Area, Southwestern Nigeria. Research Journal in Engineering and Applied Sciences, 1, 7-11.

[17] Gebhardt, H., Adekeye, O.A. and Akande, S.O. (2010) Late Paleocene to Initial Eocene Thermal Maximum Foraminifera Biostratigarphy and Paleoecology of the 
Dahomey Basin, Southwestern Nigeria. Gjahrbuch Der Geologischem Bundesantalt, 150, 407-419.

[18] Olabode, S.O. (2007) Lithofacies Characterization and Channel Development in the Outcrops of Cretaceous Sedimentary Rocks, Eastern Dahomey Basin, South Western Nigeria. Journal of Mining and Geology, 43, 131-145.

[19] Brownfield, M.E. and Charpentier, R.R. (2006) Geology and Total petroleum systems of the Gulf of Guinea Province, West Africa. U.S. Geological Survey Bulletin, 2207-C, 32 p.

[20] Elvsborg, A. and Dalode, J. (1985) Benin Hydrocarbon Potential Looks Promising. Oil Gas Journal, 83, 126-131.

[21] Fayose, E.A. and Azeez, L.O. (1972) Micropaleontological Investigation of Ewekoro Formation, Southwestern Nigeria. Micropaleontology, 18, 69-332. https://doi.org/10.2307/1485014

[22] Flugel, E. (1982) Microfacies Analysis of Limestones. Springer-Verley, Berlin, Heidelberg, New York, 633 p. https://doi.org/10.1007/978-3-642-68423-4

[23] Pettijohn, F.J. (1975) Sedimentary Rocks. 3rd Edition, Harper and Row, New York, $628 \mathrm{p}$.

[24] Roser, B.P. and Korsch, R.J. (1986) Determination of Tectonic Setting of Sandstone-Mudstone Suites Using $\mathrm{SiO}_{2}$ Content and $\mathrm{K}_{2} \mathrm{O} / \mathrm{Na}_{2} \mathrm{O}$ Ratio. Journal of Geology, 94, 635-650. https://doi.org/10.1086/629071

[25] Roser, B.P. and Korsch, R.J. (1988) Provenance Signatures of Sandstone-Mudstone Suite Determined Using Discriminant Function Analysis of Major Element Data. Chemical Geology, 67, 119-139. https://doi.org/10.1016/0009-2541(88)90010-1

[26] Dunham, R.J. (1962) Classification of Carbonate Rocks According to Depositional Texture. In: Ham, W.E., Ed., Classification of Carbonate Rock, American Association of Petroleum Geologists Memoir, 108-201.

[27] Folk, R.L. (1974) Petrography of Sedimentary Rocks. Hemphill Publishing Company, Austin, Texas, $182 \mathrm{p}$.

[28] Armstrong-Altrin, J.S., Lee, Y.I., Verma, S.P. and Ramasamy, S. (2004) Geochemistry of 373 Sandstones from the Upper Miocene Kudankulam Formation, Southern India: Implications for 374 Provenance, Weathering, and Tectonic Setting. Journal of Sedimentary Research, 74, 285-297. https://doi.org/10.1306/082803740285 


\section{Appendix}

Table 1. Major elemental geochemistry of the Akinbo and Ewekoro Formations in Well 1.

\begin{tabular}{|c|c|c|c|c|c|c|c|c|c|c|c|c|c|c|c|c|}
\hline $\begin{array}{l}\text { Depth } \\
(\mathrm{m})\end{array}$ & $\begin{array}{c}\mathrm{CaO} \\
(\%)\end{array}$ & $\begin{array}{c}\mathrm{SiO}_{2} \\
(\%)\end{array}$ & $\begin{array}{c}\mathrm{Al}_{2} \mathrm{O}_{3} \\
(\%)\end{array}$ & $\begin{array}{c}\mathrm{Fe}_{2} \mathrm{O}_{3} \\
(\%)\end{array}$ & $\begin{array}{c}\mathrm{MgO} \\
(\%)\end{array}$ & $\begin{array}{l}\mathrm{K}_{2} \mathrm{O} \\
(\%)\end{array}$ & $\begin{array}{c}\mathrm{SiO}_{2} \\
(\%)\end{array}$ & $\mathrm{Mg} / \mathrm{Ca}$ & $\mathrm{Fe} / \mathrm{Ca}$ & $\mathrm{Si} / \mathrm{Ca}$ & $\mathrm{Fe} / \mathrm{Mg}$ & $\mathrm{Si} / \mathrm{Al}$ & $\mathrm{Ca} / \mathrm{Mg}$ & $\mathrm{Mg} / \mathrm{Ca}$ & $\mathrm{Fe} / \mathrm{Ca}$ & $\mathrm{Si} / \mathrm{Ca}$ \\
\hline 1.00 & 0.22 & 77.49 & 9.50 & 4.20 & 0.19 & 0.77 & 77.49 & 0.863636 & 19.09091 & 352.2273 & 22.10526 & 8.156842 & 1.157895 & 0.863636 & 19.09091 & 352.2273 \\
\hline 1.50 & 0.17 & 65.27 & 14.71 & 6.20 & 0.36 & 0.70 & 65.27 & 2.117647 & 36.47059 & 383.9412 & 17.22222 & 4.437118 & 0.472222 & 2.117647 & 36.47059 & 383.9412 \\
\hline 2.00 & 0.18 & 65.94 & 13.58 & 6.75 & 0.39 & 0.82 & 65.94 & 2.166667 & 37.50000 & 366.3333 & 17.30769 & 4.855670 & 0.461538 & 2.166667 & 37.50000 & 366.3333 \\
\hline 2.50 & 0.15 & 65.25 & 14.22 & 7.12 & 0.4 & 0.88 & 65.25 & 2.666667 & 47.46667 & 435.0000 & 17.80000 & 4.588608 & 0.375000 & 2.666667 & 47.46667 & 435.0000 \\
\hline 3.00 & 0.18 & 64.32 & 1.87 & 9.16 & 0.38 & 0.84 & 64.32 & 2.111111 & 50.88889 & 357.3333 & 24.10526 & 34.39572 & 0.473684 & 2.111111 & 50.88889 & 357.3333 \\
\hline 3.50 & 0.19 & 62.96 & 15.32 & 5.84 & 0.47 & 0.84 & 62.96 & 2.473684 & 30.73684 & 331.3684 & 12.42553 & 4.109661 & 0.404255 & 2.473684 & 30.73684 & 331.3684 \\
\hline 4.00 & 0.2 & 65.32 & 14.80 & 5.45 & 0.41 & 0.82 & 65.32 & 2.050000 & 27.25000 & 326.6000 & 13.29268 & 4.413514 & 0.487805 & 2.050000 & 27.25000 & 326.6000 \\
\hline 4.50 & 0.21 & 64.19 & 14.20 & 5.13 & 0.38 & 1.54 & 64.19 & 1.809524 & 24.42857 & 305.6667 & 13.50000 & 4.520423 & 0.552632 & 1.809524 & 24.42857 & 305.6667 \\
\hline 5.00 & 0.20 & 63.82 & 15.22 & 4.98 & 0.43 & 0.87 & 63.82 & 2.150000 & 24.90000 & 319.1000 & 11.58140 & 4.193167 & 0.465116 & 2.150000 & 24.90000 & 319.1000 \\
\hline 5.50 & 51.10 & 4.44 & 0.82 & 0.44 & 1.13 & 0.17 & 4.44 & 0.022114 & 0.008611 & 0.086888 & 0.389381 & 5.414634 & 45.22124 & 0.022114 & 0.008611 & 0.086888 \\
\hline 6.00 & 52.43 & 3.61 & 0.59 & 0.39 & 1.10 & 0.27 & 3.61 & 0.020980 & 0.007438 & 0.068854 & 0.354545 & 6.118644 & 47.66364 & 0.020980 & 0.007438 & 0.068854 \\
\hline 6.55 & 51.80 & 4.94 & 0.55 & 0.40 & 1.44 & 0.08 & 4.94 & 0.027799 & 0.007722 & 0.095367 & 0.277778 & 8.981818 & 35.97222 & 0.027799 & 0.007722 & 0.095367 \\
\hline 7.00 & - & - & washout & - & - & - & - & - & - & - & - & - & - & - & - & - \\
\hline 7.50 & 52.72 & 3.48 & 0.84 & 0.48 & 0.84 & 0.06 & 3.48 & 0.015933 & 0.009105 & 0.066009 & 0.571429 & 4.142857 & 62.76190 & 0.015933 & 0.009105 & 0.066009 \\
\hline 8.05 & 52.74 & 3.32 & 0.57 & 0.52 & 1.06 & 0.72 & 3.32 & 0.020099 & 0.009860 & 0.062950 & 0.490566 & 5.824561 & 49.75472 & 0.020099 & 0.009860 & 0.062950 \\
\hline 8.50 & 51.66 & 4.82 & 0.87 & 0.52 & 1.11 & 0.07 & 4.82 & 0.021487 & 0.010066 & 0.093302 & 0.468468 & 5.540230 & 46.54054 & 0.021487 & 0.010066 & 0.093302 \\
\hline 9.00 & 51.74 & 4.16 & 0.82 & 0.50 & 1.68 & 0.08 & 4.16 & 0.032470 & 0.009664 & 0.080402 & 0.297619 & 5.073171 & 30.79762 & 0.032470 & 0.009664 & 0.080402 \\
\hline 9.50 & 52.16 & 3.27 & 0.65 & 0.36 & 106 & 0.07 & 3.27 & 2.032209 & 0.006902 & 0.062692 & 0.003396 & 5.030769 & 0.492075 & 2.032209 & 0.006902 & 0.062692 \\
\hline 10.00 & 52.58 & 3.37 & 0.59 & 0.39 & 0.98 & 0.17 & 3.37 & 0.018638 & 0.007417 & 0.064093 & 0.397959 & 5.711864 & 53.65306 & 0.018638 & 0.007417 & 0.064093 \\
\hline 10.50 & 52.52 & 3.90 & 0.47 & 0.32 & 0.83 & 0.16 & 3.90 & 0.015804 & 0.006093 & 0.074257 & 0.385542 & 8.297872 & 63.27711 & 0.015804 & 0.006093 & 0.074257 \\
\hline 11.00 & 52.16 & 3.51 & 0.52 & 0.35 & 0.70 & 0.06 & 3.51 & 0.013420 & 0.006710 & 0.067293 & 0.500000 & 6.750000 & 74.51429 & 0.013420 & 0.006710 & 0.067293 \\
\hline 11.50 & 51.80 & 4.36 & 0.85 & 0.42 & 1.18 & 0.12 & 4.36 & 0.022780 & 0.008108 & 0.084170 & 0.355932 & 5.129412 & 43.89831 & 0.022780 & 0.008108 & 0.084170 \\
\hline 12.00 & 51.85 & 4.06 & 0.90 & 0.45 & 1.11 & 0.19 & 4.06 & 0.021408 & 0.008679 & 0.078303 & 0.405405 & 4.511111 & 46.71171 & 0.021408 & 0.008679 & 0.078303 \\
\hline 12.30 & - & - & washout & - & - & - & - & - & - & - & - & - & - & - & - & - \\
\hline 12.50 & 51.84 & 4.90 & 0.54 & 0.38 & 0.98 & 0.05 & 4.90 & 0.018904 & 0.007330 & 0.094522 & 0.387755 & 9.074074 & 52.89796 & 0.018904 & 0.007330 & 0.094522 \\
\hline 13.00 & 52.56 & 3.75 & 0.45 & 0.44 & 1.01 & 0.05 & 3.75 & 0.019216 & 0.008371 & 0.071347 & 0.435644 & 8.333333 & 52.03960 & 0.019216 & 0.008371 & 0.071347 \\
\hline 13.50 & 44.31 & 10.38 & 1.65 & 1.14 & 4.84 & 0.10 & 10.38 & 0.109230 & 0.025728 & 0.234259 & 0.235537 & 6.290909 & 9.154959 & 0.109230 & 0.025728 & 0.234259 \\
\hline 14.00 & 53.10 & 2.40 & 0.45 & 0.38 & 1.06 & 0.14 & 2.40 & 0.019962 & 0.007156 & 0.045198 & 0.358491 & 5.333333 & 50.09434 & 0.019962 & 0.007156 & 0.045198 \\
\hline 14.50 & 51.74 & 4.43 & 0.57 & 0.42 & 1.02 & 0.06 & 4.43 & 0.019714 & 0.008118 & 0.085620 & 0.411765 & 7.771930 & $\mathrm{Na}$ & 0.019714 & 0.008118 & 0.085620 \\
\hline 15.00 & 52.54 & 3.02 & 0.49 & 0.32 & 0.90 & 0.06 & 3.02 & 0.017130 & 0.006091 & 0.057480 & 0.355556 & 6.163265 & $\mathrm{Na}$ & 0.017130 & 0.006091 & 0.057480 \\
\hline 15.50 & 53.19 & 2.98 & 0.42 & 0.38 & 0.91 & 0.04 & 2.98 & 0.017108 & 0.007144 & 0.056026 & 0.417582 & 7.095238 & $\mathrm{Na}$ & 0.017108 & 0.007144 & 0.056026 \\
\hline 16.00 & 53.14 & 2.47 & 0.48 & 0.40 & 0.72 & 0.05 & 2.47 & 0.013549 & 0.007527 & 0.046481 & 0.555556 & 5.145833 & $\mathrm{Na}$ & 0.013549 & 0.007527 & 0.046481 \\
\hline 16.50 & 51.59 & 4.48 & 0.94 & 0.53 & 1.18 & 0.06 & 4.48 & 0.022873 & 0.010273 & 0.086839 & 0.449153 & 4.765957 & $\mathrm{Na}$ & 0.022873 & 0.010273 & 0.086839 \\
\hline 17.00 & 52.37 & 3.28 & 0.84 & 0.55 & 0.96 & 0.05 & 3.28 & 0.018331 & 0.010502 & 0.062631 & 0.572917 & 3.904762 & $\mathrm{Na}$ & 0.018331 & 0.010502 & 0.062631 \\
\hline 17.50 & 49.31 & 7.32 & 0.75 & 0.56 & 1.12 & 0.06 & 7.32 & 0.022713 & 0.011357 & 0.148449 & 0.500000 & 9.760000 & $\mathrm{Na}$ & 0.022713 & 0.011357 & 0.148449 \\
\hline 18.00 & 51.7 & 4.13 & 0.48 & 0.42 & 1.15 & 0.14 & 4.13 & 0.022244 & 0.008124 & 0.079884 & 0.365217 & 8.604167 & $\mathrm{Na}$ & 0.022244 & 0.008124 & 0.079884 \\
\hline 18.50 & 49.16 & 8.67 & 0.92 & 0.47 & 0.82 & 0.04 & 8.67 & 0.016680 & 0.009561 & 0.176363 & 0.573171 & 9.423913 & $\mathrm{Na}$ & 0.016680 & 0.009561 & 0.176363 \\
\hline
\end{tabular}


Table 2. Major elemental geochemistry of the Akinbo and Ewekoro Formations in Well-2.

\begin{tabular}{|c|c|c|c|c|c|c|c|c|c|c|c|c|}
\hline Depth (m) & $\mathrm{CaO}(\%)$ & $\mathrm{SiO}_{2}(\%)$ & $\mathrm{Al}_{2} \mathrm{O}_{3}(\%)$ & $\mathrm{Fe}_{2} \mathrm{O}_{3}(\%)$ & $\mathrm{MgO}(\%)$ & $\mathrm{K}_{2} \mathrm{O}(\%)$ & $\mathrm{Mg} / \mathrm{Ca}$ & $\mathrm{Fe} / \mathrm{Ca}$ & $\mathrm{Si} / \mathrm{Ca}$ & $\mathrm{Fe} / \mathrm{Mg}$ & $\mathrm{Si} / \mathrm{Al}$ & $\mathrm{Ca} / \mathrm{Mg}$ \\
\hline 0.50 & 0.16 & 72.36 & 10.16 & 5.38 & 0.15 & 0.10 & 0.937500 & 33.62500 & 452.2500 & 35.86667 & 7.122047 & 1.066667 \\
\hline 1.00 & 0.14 & 6.77 & 15.68 & 6.65 & 0.40 & 0.80 & 2.857143 & 47.50000 & 48.35714 & 16.62500 & 0.431760 & 0.350000 \\
\hline 1.50 & 0.15 & 62.85 & 14.76 & 5.57 & 0.19 & 0.29 & 1.266667 & 37.13333 & 419.0000 & 29.31579 & 4.258130 & 0.789474 \\
\hline 2.00 & 0.13 & 63.82 & 14.72 & 6.48 & 0.31 & 0.62 & 2.384615 & 49.84615 & 490.9231 & 20.90323 & 4.335598 & 0.419355 \\
\hline 2.50 & 0.12 & 62.94 & 15.37 & 5.94 & 0.37 & 0.76 & 3.083333 & 49.50000 & 524.5000 & 16.05405 & 4.094990 & 0.324324 \\
\hline 3.00 & 0.14 & 60.85 & 14.13 & 5.30 & 0.26 & 0.39 & 1.857143 & 37.85714 & 434.6429 & 20.38462 & 4.306440 & 0.538462 \\
\hline 3.50 & 0.14 & 62.86 & 14.12 & 7.24 & 0.36 & 0.79 & 2.571429 & 51.71429 & 449.0000 & 20.11111 & 4.451841 & 0.388889 \\
\hline 4.00 & 0.19 & 63.75 & 14.45 & 4.98 & 0.47 & 0.90 & 2.473684 & 26.21053 & 335.5263 & 10.59574 & 4.411765 & 0.404255 \\
\hline 4.50 & 0.17 & 62.93 & 14.10 & 6.18 & 0.14 & 0.79 & 0.823529 & 36.35294 & 370.1765 & 44.14286 & 4.463121 & 1.214286 \\
\hline 5.00 & 0.19 & 65.27 & 16.26 & 5.30 & 0.47 & 0.94 & 2.473684 & 27.89474 & 343.5263 & 11.27660 & 4.014145 & 0.404255 \\
\hline 5.50 & 0.18 & 63.79 & 15.15 & 5.18 & 0.38 & 0.92 & 2.111111 & 28.77778 & 354.3889 & 13.63158 & 4.210561 & 0.473684 \\
\hline 6.00 & 0.16 & 67.62 & 11.14 & 5.30 & 0.35 & 0.35 & 2.187500 & 33.12500 & 422.6250 & 15.14286 & 6.070018 & 0.457143 \\
\hline 6.50 & 0.19 & 62.90 & 15.92 & 5.17 & 0.39 & 0.97 & 2.052632 & 27.21053 & 331.0526 & 13.25641 & 3.951005 & 0.487179 \\
\hline 6.90 & 0.30 & 65.72 & 13.47 & 5.31 & 0.29 & 1.79 & 0.966667 & 17.70000 & 219.0667 & 18.31034 & 4.878990 & 1.034483 \\
\hline 7.50 & 49.43 & 8.12 & 2.27 & 1.27 & 1.15 & 0.13 & 0.023265 & 0.025693 & 0.164273 & 1.104348 & 3.577093 & 42.98261 \\
\hline 8.00 & 52.45 & 2.76 & 0.49 & 0.35 & 0.67 & 0.09 & 0.012774 & 0.006673 & 0.052622 & 0.522388 & 5.632653 & 78.28358 \\
\hline 8.50 & 53.31 & 2.15 & 0.35 & 0.22 & 0.50 & 0.06 & 0.009379 & 0.004127 & 0.040330 & 0.440000 & 6.142857 & 106.6200 \\
\hline 9.00 & 53.35 & 2.74 & 0.45 & 0.35 & 0.52 & 0.06 & 0.009747 & 0.006560 & 0.051359 & 0.673077 & 6.088889 & 102.5962 \\
\hline 9.50 & 49.63 & 6.22 & 0.97 & 0.65 & 0.77 & 0.05 & 0.015515 & 0.013097 & 0.125327 & 0.844156 & 6.412371 & 64.45455 \\
\hline 10.00 & 51.87 & 4.80 & 0.45 & 0.37 & 0.66 & 0.06 & 0.012724 & 0.007133 & 0.092539 & 0.560606 & 10.66667 & 78.59091 \\
\hline 10.50 & 53.55 & 2.32 & 0.39 & 0.32 & 0.75 & 0.05 & 0.014006 & 0.005976 & 0.043324 & 0.426667 & 5.948718 & 71.40000 \\
\hline 11.00 & 52.25 & 3.80 & 0.47 & 0.38 & 0.65 & 0.06 & 0.012440 & 0.007273 & 0.072727 & 0.584615 & 8.085106 & 80.38462 \\
\hline 11.50 & 53.34 & 2.30 & 0.47 & 0.32 & 0.67 & 0.05 & 0.012561 & 0.005999 & 0.043120 & 0.477612 & 4.893617 & 79.61194 \\
\hline 12.00 & 52.48 & 3.26 & 0.38 & 0.28 & 0.52 & 0.04 & 0.009909 & 0.005335 & 0.062119 & 0.538462 & 8.578947 & 100.9231 \\
\hline 12.50 & 53.49 & 2.16 & 0.42 & 0.25 & 0.49 & 0.05 & 0.009161 & 0.004674 & 0.040381 & 0.510204 & 5.142857 & 109.1633 \\
\hline 13.00 & 53.44 & 2.90 & 0.44 & 0.36 & 0.56 & 0.38 & 0.010479 & 0.006737 & 0.054266 & 0.642857 & 6.590909 & 95.42857 \\
\hline 13.50 & 52.57 & 3.67 & 0.45 & 0.34 & 0.52 & 0.05 & 0.009892 & 0.006468 & 0.069812 & 0.653846 & 8.155556 & 101.0962 \\
\hline 14.00 & 53.88 & 2.40 & 0.73 & 0.35 & 0.68 & 0.06 & 0.012621 & 0.006496 & 0.044543 & 0.514706 & 3.287671 & 79.23529 \\
\hline 14.60 & 51.90 & 4.25 & 0.60 & 0.40 & 1.02 & 0.07 & 0.019653 & 0.007707 & 0.081888 & 0.392157 & 7.083333 & 50.88235 \\
\hline 15.00 & - & - & washout & - & - & - & - & - & - & - & - & - \\
\hline 15.50 & 48.67 & 7.40 & 0.80 & 0.59 & 2.52 & 0.09 & 0.051777 & 0.012122 & 0.152044 & 0.234127 & 9.250000 & 19.31349 \\
\hline 16.00 & 51.33 & 4.29 & 0.45 & 0.37 & 1.32 & 0.08 & 0.025716 & 0.007208 & 0.083577 & 0.280303 & 9.533333 & 38.88636 \\
\hline 16.50 & 54.39 & 1.36 & 0.58 & 0.47 & 0.95 & 0.06 & 0.017466 & 0.008641 & 0.025005 & 0.494737 & 2.344828 & 57.25263 \\
\hline 17.00 & 53.99 & 2.19 & 0.52 & 0.32 & 0.76 & 0.06 & 0.014077 & 0.005927 & 0.040563 & 0.421053 & 4.211538 & 71.03947 \\
\hline 17.50 & 53.23 & 2.59 & 0.56 & 0.49 & 0.57 & 0.05 & 0.010708 & 0.009205 & 0.048657 & 0.859649 & 4.625000 & 93.38596 \\
\hline 18.00 & 51.18 & 4.33 & 0.83 & 0.44 & 1.10 & 0.07 & 0.021493 & 0.008597 & 0.084603 & 0.400000 & 5.216867 & 46.52727 \\
\hline 18.60 & 51.99 & 4.44 & 0.68 & 0.39 & 1.28 & 0.03 & 0.024620 & 0.007501 & 0.085401 & 0.304688 & 6.529412 & 40.61719 \\
\hline 19.50 & 49.23 & 8.44 & 0.52 & 0.45 & 1.23 & 0.13 & 0.024985 & 0.009141 & 0.171440 & 0.365854 & 16.23077 & 40.02439 \\
\hline 20.00 & 47.13 & 10.24 & 1.54 & 1.20 & 1.22 & 0.12 & 0.025886 & 0.025461 & 0.217271 & 0.983607 & 6.649351 & 38.63115 \\
\hline 20.50 & 48.94 & 7.52 & 0.82 & 0.67 & 0.71 & 0.06 & 0.014508 & 0.013690 & 0.153658 & 0.943662 & 9.170732 & 68.92958 \\
\hline
\end{tabular}


Table 3. Major elemental geochemistry of the Akinbo and Ewekoro Formation in Well-3.

\begin{tabular}{|c|c|c|c|c|c|c|c|c|c|c|c|c|}
\hline Depth (m) & $\mathrm{CaO}(\%)$ & $\mathrm{SiO}_{2}(\%)$ & $\mathrm{Al}_{2} \mathrm{O}_{3}(\%)$ & $\mathrm{Fe}_{2} \mathrm{O}_{3}(\%)$ & $\mathrm{MgO}(\%)$ & $\mathrm{K}_{2} \mathrm{O}(\%)$ & $\mathrm{Mg} / \mathrm{Ca}$ & $\mathrm{Fe} / \mathrm{Ca}$ & $\mathrm{Si} / \mathrm{Ca}$ & $\mathrm{Fe} / \mathrm{Mg}$ & $\mathrm{Si} / \mathrm{Al}$ & $\mathrm{Ca} / \mathrm{Mg}$ \\
\hline 1.00 & 0.18 & 72.79 & 10.65 & 6.25 & 0.19 & 0.12 & 1.055556 & 34.72222 & 404.3889 & 32.89474 & 6.834742 & 0.947368 \\
\hline 1.50 & 0.13 & 63.42 & 12.89 & 9.27 & 0.28 & 0.55 & 2.153846 & 71.30769 & 487.8462 & 33.10714 & 4.920093 & 0.464286 \\
\hline 2.00 & 0.1 & 64.42 & 12.19 & 11.14 & 0.31 & 0.71 & 3.100000 & 111.4000 & 644.2000 & 35.93548 & 5.284660 & 0.322581 \\
\hline 2.50 & 0.14 & 62.57 & 12.86 & 8.17 & 0.33 & 0.75 & 2.357143 & 58.35714 & 446.9286 & 24.75758 & 4.865474 & 0.424242 \\
\hline 3.00 & 0.16 & 63.92 & 11.14 & 7.32 & 0.29 & 0.71 & 1.812500 & 45.75000 & 399.5000 & 25.24138 & 5.737882 & 0.551724 \\
\hline 3.50 & 0.44 & 65.95 & 12.9 & 4.26 & 0.21 & 1.38 & 0.477273 & 9.681818 & 149.8864 & 20.28571 & 5.112403 & 2.095238 \\
\hline 4.00 & 0.28 & 64.52 & 10.57 & 7.44 & 0.2 & 1.27 & 0.714286 & 26.57143 & 230.4286 & 37.20000 & 6.104068 & 1.400000 \\
\hline 4.50 & 0.12 & 63.94 & 11.27 & 8.57 & 0.27 & 1.93 & 2.250000 & 71.41667 & 532.8333 & 31.74074 & 5.673469 & 0.444444 \\
\hline 5.00 & 0.11 & 62.67 & 13.32 & 8.36 & 0.26 & 2.79 & 2.363636 & 76.00000 & 569.7273 & 32.15385 & 4.704955 & 0.423077 \\
\hline 5.50 & 52.4 & 3.30 & 0.75 & 0.60 & 0.57 & 0.06 & 0.010878 & 0.011450 & 0.062977 & 1.052632 & 4.400000 & 91.92982 \\
\hline 6.00 & - & - & - & washout & - & - & - & - & - & - & - & - \\
\hline 6.50 & 40.21 & 18.2 & 4.22 & 2.72 & 1.13 & 0.04 & 0.028102 & 0.067645 & 0.452624 & 2.407080 & 4.312796 & 35.58407 \\
\hline 7.00 & 52.69 & 3.76 & 0.84 & 0.46 & 0.56 & 0.07 & 0.010628 & 0.00873 & 0.071361 & 0.821429 & 4.476190 & 94.08929 \\
\hline 7.50 & 52.12 & 3.68 & 0.65 & 0.54 & 0.48 & 0.06 & 0.00921 & 0.010361 & 0.070606 & 1.125000 & 5.661538 & 108.5833 \\
\hline 8.00 & 53.74 & 2.5 & 0.34 & 0.29 & 0.38 & 0.06 & 0.007071 & 0.005396 & 0.046520 & 0.763158 & 7.352941 & 141.4211 \\
\hline 8.50 & 52.44 & 3.34 & 0.52 & 0.42 & 0.32 & 0.05 & 0.006102 & 0.008009 & 0.063692 & 1.312500 & 6.423077 & 163.8750 \\
\hline 9.00 & 54.19 & 1.43 & 0.34 & 0.28 & 0.40 & 0.08 & 0.007381 & 0.005167 & 0.026389 & 0.700000 & 4.205882 & 135.4750 \\
\hline 9.50 & 53.37 & 2.17 & 0.59 & 0.36 & 0.54 & 0.09 & 0.010118 & 0.006745 & 0.040660 & 0.666667 & 3.677966 & 98.83333 \\
\hline 10.00 & 52.22 & 3.55 & 0.75 & 0.55 & 0.52 & 0.05 & 0.009958 & 0.010532 & 0.067982 & 1.057692 & 4.733333 & 100.4231 \\
\hline 10.50 & - & - & - & washout & - & - & - & - & - & - & - & - \\
\hline 11.00 & 53.94 & 2.27 & 0.56 & 0.32 & 0.32 & 0.06 & 0.005933 & 0.005933 & 0.042084 & 1.000000 & 4.053571 & 168.5625 \\
\hline 11.50 & 54.15 & 1.25 & 0.45 & 0.32 & 0.36 & 0.16 & 0.006648 & 0.005910 & 0.023084 & 0.888889 & 2.777778 & 150.4167 \\
\hline 12.00 & 53.94 & 2.66 & 0.44 & 0.21 & 0.49 & 0.06 & 0.009084 & 0.003893 & 0.049314 & 0.428571 & 6.045455 & 110.0816 \\
\hline 12.50 & 53.72 & 2.41 & 0.2 & 0.36 & 0.51 & 0.11 & 0.009494 & 0.006701 & 0.044862 & 0.705882 & 12.05000 & 105.3333 \\
\hline 13.00 & 53.51 & 2.82 & 0.45 & 0.32 & 0.64 & 0.04 & 0.011960 & 0.005980 & 0.052700 & 0.500000 & 6.266667 & 83.60938 \\
\hline 13.50 & 52.32 & 3.63 & 0.58 & 0.45 & 0.92 & 0.04 & 0.017584 & 0.008601 & 0.069381 & 0.489130 & 6.258621 & 56.86957 \\
\hline 13.70 & 48.42 & 7.69 & 1.55 & 1.03 & 3.71 & 0.06 & 0.076621 & 0.021272 & 0.158819 & 0.277628 & 4.961290 & 13.05121 \\
\hline 14.20 & - & - & - & washout & - & - & - & - & - & - & - & - \\
\hline 14.50 & 48.42 & 7.69 & 1.55 & 1.03 & 3.71 & 0.06 & 0.076621 & 0.021272 & 0.158819 & 0.277628 & 4.961290 & 13.05121 \\
\hline 15.00 & 48.84 & 5.32 & 1.85 & 1.10 & 2.36 & 0.06 & 0.048321 & 0.022523 & 0.108927 & 0.466102 & 2.875676 & 20.69492 \\
\hline 15.50 & 51.75 & 4.37 & 0.87 & 0.45 & 1.32 & 0.05 & 0.025507 & 0.008696 & 0.084444 & 0.340909 & 5.022989 & 39.20455 \\
\hline 16.00 & 51.96 & 4.03 & 1.48 & 1.20 & 1.12 & 0.08 & 0.021555 & 0.023095 & 0.077560 & 1.071429 & 2.722973 & 46.39286 \\
\hline 16.60 & 48.73 & 6.73 & 1.48 & 1.20 & 1.12 & 0.08 & 0.022984 & 0.024625 & 0.138108 & 1.071429 & 4.547297 & 43.50893 \\
\hline 17.70 & - & - & - & washout & - & - & - & - & - & - & - & - \\
\hline 18.00 & 48.87 & 8.13 & 0.92 & 0.68 & 1.07 & 0.04 & 0.021895 & 0.013914 & 0.166360 & 0.635514 & 8.836957 & 45.67290 \\
\hline 18.50 & 49.37 & 8.24 & 0.84 & 0.74 & 0.82 & 0.05 & 0.016609 & 0.014989 & 0.166903 & 0.902439 & 9.809524 & 60.20732 \\
\hline 19.00 & 48.85 & 8.22 & 0.82 & 0.58 & 0.49 & 0.06 & 0.010031 & 0.011873 & 0.168270 & 1.183673 & 10.02439 & 99.69388 \\
\hline
\end{tabular}


Table 4. Major elemental geochemistry of the Akinbo and Ewekoro Formations in Well-4.

\begin{tabular}{|c|c|c|c|c|c|c|c|c|c|c|c|c|}
\hline Depth (m) & $\mathrm{CaO}(\%)$ & $\mathrm{SiO}_{2}(\%)$ & $\mathrm{Al}_{2} \mathrm{O}_{3}(\%)$ & $\mathrm{Fe}_{2} \mathrm{O}_{3}(\%)$ & $\mathrm{MgO}(\%)$ & $\mathrm{K}_{2} \mathrm{O}(\%)$ & $\mathrm{Mg} / \mathrm{Ca}$ & $\mathrm{Fe} / \mathrm{Ca}$ & $\mathrm{Si} / \mathrm{Ca}$ & $\mathrm{Fe} / \mathrm{Mg}$ & $\mathrm{Si} / \mathrm{Al}$ & $\mathrm{Ca} / \mathrm{Mg}$ \\
\hline 1.00 & 0.13 & 72.7 & 10.34 & 5.16 & 0.18 & 0.19 & 1.384615 & 39.66154 & 559.2308 & 28.64444 & 7.030948 & 0.722222 \\
\hline 1.50 & 0.18 & 72.31 & 11.31 & 5.31 & 0.16 & 0.24 & 0.888889 & 29.50000 & 401.7222 & 33.1875 & 6.393457 & 1.125000 \\
\hline 2.00 & 0.19 & 65.83 & 12.81 & 8.35 & 0.30 & 4.68 & 1.578947 & 43.94737 & 346.4737 & 27.83333 & 5.138954 & 0.633333 \\
\hline 2.50 & 0.16 & 64.25 & 12.75 & 10.23 & 0.27 & 3.44 & 1.687500 & 63.93750 & 401.5625 & 37.88889 & 5.039216 & 0.592593 \\
\hline 3.00 & 51.26 & 4.15 & 0.82 & 0.62 & 0.69 & 0.11 & 0.013461 & 0.012095 & 0.080960 & 0.898551 & 5.060976 & 74.28986 \\
\hline 3.30 & 53.73 & 2.24 & 0.55 & 0.34 & 0.51 & 0.06 & 0.009492 & 0.006328 & 0.041690 & 0.666667 & 4.072727 & 105.3529 \\
\hline 4.00 & 52.84 & 3.44 & 0.49 & 0.38 & 0.54 & 0.65 & 0.010220 & 0.007192 & 0.065102 & 0.703704 & 7.020408 & 97.85185 \\
\hline 4.50 & 53.49 & 2.31 & 0.65 & 0.53 & 0.51 & 0.06 & 0.009534 & 0.009908 & 0.043186 & 1.039216 & 3.553846 & 104.8824 \\
\hline 5.00 & 54.68 & 1.47 & 0.56 & 0.45 & 0.50 & 0.08 & 0.009144 & 0.008230 & 0.026884 & 0.900000 & 2.625000 & 109.3600 \\
\hline 5.50 & 54.39 & 1.45 & 0.49 & 0.28 & 0.34 & 0.05 & 0.006251 & 0.005148 & 0.026659 & 0.823529 & 2.959184 & 159.9706 \\
\hline 6.00 & 53.63 & 2.60 & 0.52 & 0.35 & 0.35 & 0.13 & 0.006526 & 0.006526 & 0.048480 & 1.000000 & 5.000000 & 153.2286 \\
\hline 6.50 & 53.84 & 2.49 & 0.64 & 0.52 & 0.34 & 0.07 & 0.006315 & 0.009658 & 0.046248 & 1.529412 & 3.890625 & 158.3529 \\
\hline 7.00 & 53.17 & 2.94 & 0.52 & 0.40 & 0.25 & 0.08 & 0.004702 & 0.007523 & 0.055294 & 1.600000 & 5.653846 & 212.6800 \\
\hline 7.50 & 54.62 & 1.69 & 0.40 & 0.24 & 0.29 & 0.06 & 0.005309 & 0.004394 & 0.030941 & 0.827586 & 4.225000 & 188.3448 \\
\hline 8.00 & 54.36 & 1.59 & 0.45 & 0.35 & 0.38 & 0.05 & 0.006990 & 0.006439 & 0.029249 & 0.921053 & 3.533333 & 143.0526 \\
\hline 8.50 & 48.11 & 7.17 & 1.95 & 0.86 & 0.97 & 0.11 & 0.020162 & 0.017876 & 0.149033 & 0.886598 & 3.676923 & 49.59794 \\
\hline 9.00 & 48.35 & 6.75 & 1.65 & 1.00 & 1.20 & 0.21 & 0.024819 & 0.020683 & 0.139607 & 0.833333 & 4.090909 & 40.29167 \\
\hline 9.50 & 51.40 & 4.31 & 0.55 & 0.42 & 1.37 & 0.09 & 0.026654 & 0.008171 & 0.083852 & 0.306569 & 7.836364 & 37.51825 \\
\hline 10.00 & 52.29 & 3.34 & 0.72 & 0.65 & 0.89 & 0.05 & 0.017020 & 0.012431 & 0.063875 & 0.730337 & 4.638889 & 58.75281 \\
\hline 10.50 & 52.79 & 3.45 & 0.60 & 0.44 & 0.88 & 0.05 & 0.016670 & 0.008335 & 0.065353 & 0.500000 & 5.750000 & 59.98864 \\
\hline 11.00 & 53.12 & 2.93 & 0.67 & 0.47 & 0.92 & 0.05 & 0.017319 & 0.008848 & 0.055158 & 0.510870 & 4.373134 & 57.73913 \\
\hline 11.50 & 53.19 & 2.30 & 0.57 & 0.45 & 0.68 & 0.05 & 0.012784 & 0.008460 & 0.043241 & 0.661765 & 4.035088 & 78.22059 \\
\hline 12.00 & 52.37 & 3.21 & 0.54 & 0.38 & 0.86 & 0.05 & 0.016422 & 0.007256 & 0.061295 & 0.441860 & 5.944444 & 60.89535 \\
\hline 12.50 & 52.24 & 3.62 & 0.54 & 0.42 & 0.87 & 0.08 & 0.016654 & 0.008040 & 0.069296 & 0.482759 & 6.703704 & 60.04598 \\
\hline 13.00 & 51.69 & 4.24 & 0.62 & 0.45 & 0.91 & 0.04 & 0.017605 & 0.008706 & 0.082027 & 0.494505 & 6.838710 & 56.80220 \\
\hline 13.50 & 51.33 & 4.50 & 0.92 & 0.82 & 0.8 & 0.05 & 0.015585 & 0.015975 & 0.087668 & 1.025000 & 4.891304 & 64.16250 \\
\hline 14.00 & 51.92 & 4.32 & 0.82 & 0.62 & 0.77 & 0.04 & 0.014831 & 0.011941 & 0.083205 & 0.805195 & 5.268293 & 67.42857 \\
\hline 14.50 & 50.05 & 5.36 & 0.96 & 0.85 & 1.03 & 0.05 & 0.020579 & 0.016983 & 0.107093 & 0.825243 & 5.583333 & 48.59223 \\
\hline 15.00 & 48.21 & 8.26 & 1.27 & 0.85 & 0.98 & 0.05 & 0.020328 & 0.017631 & 0.171334 & 0.867347 & 6.503937 & 49.19388 \\
\hline 15.50 & 46.48 & 10.56 & 2.54 & 1.24 & 1.11 & 0.12 & 0.023881 & 0.026678 & 0.227194 & 1.117117 & 4.157480 & 41.87387 \\
\hline
\end{tabular}


Table 5. Major elemental geochemistry of the Akinbo and Ewekoro Formations in Well-5.

\begin{tabular}{|c|c|c|c|c|c|c|c|c|c|c|c|c|}
\hline Depth (m) & $\mathrm{CaO}(\%)$ & $\mathrm{SiO}_{2}(\%)$ & $\mathrm{Al}_{2} \mathrm{O}_{3}(\%)$ & $\mathrm{Fe}_{2} \mathrm{O}_{3}(\%)$ & $\mathrm{MgO}(\%)$ & $\mathrm{K}_{2} \mathrm{O}(\%)$ & $\mathrm{Mg} / \mathrm{Ca}$ & $\mathrm{Fe} / \mathrm{Ca}$ & $\mathrm{Si} / \mathrm{Ca}$ & $\mathrm{Fe} / \mathrm{Mg}$ & $\mathrm{Si} / \mathrm{Al}$ & $\mathrm{Ca} / \mathrm{Mg}$ \\
\hline 1.00 & 0.14 & 30.47 & 8.62 & 4.34 & 0.29 & 0.54 & 2.071429 & 31.00000 & 217.6429 & 14.96552 & 3.534803 & 0.482759 \\
\hline 1.50 & 0.18 & 70.77 & 12.37 & 6.04 & 0.22 & 0.17 & 1.222222 & 33.55556 & 393.1667 & 27.45455 & 5.721099 & 0.818182 \\
\hline 2.00 & 0.10 & 68.47 & 1362 & 7.14 & 0.29 & 0.24 & 2.900000 & 71.40000 & 684.7000 & 24.62069 & 0.050272 & 0.344828 \\
\hline 2.55 & 0.15 & 64.84 & 12.6 & 8.30 & 0.17 & 0.22 & 1.133333 & 55.33333 & 432.2667 & 48.82353 & 5.146032 & 0.882353 \\
\hline 3.00 & 54.10 & 1.45 & 0.49 & 0.35 & 0.44 & 0.06 & 0.008133 & 0.006470 & 0.026802 & 0.795455 & 2.959184 & 122.9545 \\
\hline 3.50 & 53.91 & 2.80 & 0.56 & 0.39 & 0.43 & 0.08 & 0.007976 & 0.007234 & 0.051938 & 0.906977 & 5.000000 & 125.3721 \\
\hline 4.00 & 53.22 & 2.16 & 0.54 & 0.43 & 0.45 & 0.16 & 0.008455 & 0.008080 & 0.040586 & 0.955556 & 4.000000 & 118.2667 \\
\hline 4.40 & - & - & - & washout & - & - & - & - & - & - & - & \\
\hline 4.50 & 53.22 & 2.16 & 0.54 & 0.43 & 0.45 & 0.16 & 0.008455 & 0.008080 & 0.040586 & 0.955556 & 4.000000 & 118.2667 \\
\hline 5.00 & 54.36 & 4.31 & 0.48 & 0.38 & 0.38 & 0.06 & 0.006990 & 0.006990 & 0.079286 & 1.000000 & 8.979167 & 143.0526 \\
\hline 5.50 & 52.94 & 3.46 & 0.75 & 0.47 & 0.48 & 0.05 & 0.009067 & 0.008878 & 0.065357 & 0.979167 & 4.613333 & 110.2917 \\
\hline 6.00 & 52.46 & 3.37 & 0.64 & 0.54 & 0.59 & 0.08 & 0.011247 & 0.010294 & 0.064239 & 0.915254 & 5.265625 & 88.91525 \\
\hline 6.50 & 51.70 & 4.32 & 0.62 & 0.45 & 0.96 & 0.09 & 0.018569 & 0.008704 & 0.083559 & 0.468750 & 6.967742 & 53.85417 \\
\hline 7.50 & 49.39 & 6.60 & 0.88 & 0.45 & 1.14 & 0.08 & 0.023082 & 0.009111 & 0.133630 & 0.394737 & 7.500000 & 43.32456 \\
\hline 8.00 & 52.68 & 3.34 & 0.79 & 0.44 & 0.69 & 0.05 & 0.013098 & 0.008352 & 0.063402 & 0.637681 & 4.227848 & 76.34783 \\
\hline 8.50 & 52.44 & 3.20 & 0.71 & 0.48 & 0.83 & 0.06 & 0.015828 & 0.009153 & 0.061022 & 0.578313 & 4.507042 & 63.18072 \\
\hline 9.00 & 53.57 & 2.65 & 0.55 & 0.43 & 0.57 & 0.04 & 0.010640 & 0.008027 & 0.049468 & 0.754386 & 4.818182 & 93.98246 \\
\hline 9.50 & 51.8 & 4.44 & 0.84 & 0.65 & 0.63 & 0.06 & 0.012162 & 0.012548 & 0.085714 & 1.031746 & 5.285714 & 82.22222 \\
\hline 10.00 & 51.96 & 4.80 & 0.65 & 0.35 & 0.90 & 0.05 & 0.017321 & 0.006736 & 0.092379 & 0.388889 & 7.384615 & 57.73333 \\
\hline 10.50 & 52.8 & 3.40 & 0.84 & 0.56 & 0.73 & 0.04 & 0.013826 & 0.010606 & 0.064394 & 0.767123 & 4.047619 & 72.32877 \\
\hline 11.00 & 51.50 & 4.90 & 0.82 & 0.65 & 0.32 & 0.14 & 0.006214 & 0.012621 & 0.095146 & 2.031250 & 5.975610 & 160.9375 \\
\hline 11.50 & 52.79 & 3.67 & 0.68 & 0.54 & 0.39 & 0.12 & 0.007388 & 0.010229 & 0.069521 & 1.384615 & 5.397059 & 135.3590 \\
\hline 12.00 & 51.47 & 4.73 & 0.73 & 0.48 & 1.29 & 0.15 & 0.025063 & 0.009326 & 0.091898 & 0.372093 & 6.479452 & 39.89922 \\
\hline 12.50 & 43.46 & 15.2 & 3.75 & 2.10 & 0.29 & 0.07 & 0.006673 & 0.048320 & 0.349747 & 7.241379 & 4.053333 & 149.8621 \\
\hline 13.00 & 51.62 & 4.32 & 0.62 & 0.50 & 0.30 & 0.13 & 0.005812 & 0.009686 & 0.083688 & 1.666667 & 6.967742 & 172.0667 \\
\hline 13.50 & 37.95 & 21.4 & 3.25 & 2.75 & 1.45 & 0.20 & 0.038208 & 0.072464 & 0.563900 & 1.896552 & 6.584615 & 26.17241 \\
\hline 14.00 & 51.36 & 4.73 & 0.96 & 0.84 & 0.62 & 0.15 & 0.012072 & 0.016355 & 0.092095 & 1.354839 & 4.927083 & 82.83871 \\
\hline 14.50 & 50.81 & 5.78 & 0.68 & 0.43 & 0.35 & 0.22 & 0.006888 & 0.008463 & 0.113757 & 1.228571 & 8.500000 & 145.1714 \\
\hline
\end{tabular}


Table 6. Major elemental geochemistry of the Akinbo and Ewekoro Formations in Well-6.

\begin{tabular}{|c|c|c|c|c|c|c|c|c|c|c|c|c|}
\hline Depth (m) & $\mathrm{CaO}(\%)$ & $\mathrm{SiO}_{2}(\%)$ & $\mathrm{Al}_{2} \mathrm{O}_{3}(\%)$ & $\mathrm{Fe}_{2} \mathrm{O}_{3}(\%)$ & $\mathrm{MgO}(\%)$ & $\mathrm{K}_{2} \mathrm{O}(\%)$ & $\mathrm{Mg} / \mathrm{Ca}$ & $\mathrm{Fe} / \mathrm{Ca}$ & $\mathrm{Si} / \mathrm{Ca}$ & $\mathrm{Fe} / \mathrm{Mg}$ & $\mathrm{Si} / \mathrm{Al}$ & $\mathrm{Ca} / \mathrm{Mg}$ \\
\hline 1.00 & 0.16 & 69.21 & 12.45 & 8.88 & 0.15 & 0.14 & 0.937500 & 55.50000 & 432.5625 & 59.20000 & 5.559036 & 1.066667 \\
\hline 1.50 & 0.14 & 70.5 & 10.81 & 6.26 & 0.17 & 0.10 & 1.214286 & 44.71429 & 503.5714 & 36.82353 & 6.521739 & 0.823529 \\
\hline 2.00 & 0.10 & 60.75 & 15.6 & 9.63 & 0.18 & 0.29 & 1.800000 & 96.30000 & 607.5000 & 53.50000 & 3.894231 & 0.555556 \\
\hline 2.50 & 0.11 & 61.78 & 16.22 & 9.02 & 0.19 & 0.30 & 1.727273 & 8200000 & 561.6364 & 47.47368 & 3.808878 & 0.578947 \\
\hline 3.00 & 54.13 & 1.29 & 0.49 & 0.34 & 0.37 & 0.06 & 0.006835 & 0.006281 & 0.023832 & 0.918919 & 2.632653 & 146.2973 \\
\hline 3.10 & 54.12 & 1.82 & 0.38 & 0.29 & 0.25 & 0.06 & 0.004619 & 0.005358 & 0.033629 & 1.160000 & 4.789474 & 216.4800 \\
\hline 4.00 & 54.12 & 1.82 & 0.38 & 0.29 & 0.25 & 0.06 & 0.004619 & 0.005358 & 0.033629 & 1.160000 & 4.789474 & 216.4800 \\
\hline 4.50 & 53.40 & 2.90 & 0.42 & 0.37 & 0.67 & 0.13 & 0.012547 & 0.006929 & 0.054307 & 0.552239 & 6.904762 & 79.70149 \\
\hline 5.00 & 41.63 & 19.00 & 1.98 & 1.39 & 0.78 & 0.08 & 0.018736 & 0.033389 & 0.456402 & 1.782051 & 9.595960 & 53.37179 \\
\hline 5.50 & 54.24 & 1.42 & 0.42 & 0.25 & 0.33 & 0.04 & 0.006084 & 0.004609 & 0.026180 & 0.757576 & 3.380952 & 164.3636 \\
\hline 6.00 & 51.40 & 4.37 & 0.62 & 0.42 & 0.6 & 0.12 & 0.011673 & 0.008171 & 0.085019 & 0.700000 & 7.048387 & 85.66667 \\
\hline 6.50 & 0.23 & 64.84 & 11.5 & 5.88 & 0.14 & 0.08 & 0.608696 & 25.56522 & 281.9130 & 42.00000 & 5.638261 & 1.642857 \\
\hline 7.10 & 51.12 & 4.27 & 0.59 & 0.42 & 0.22 & 0.06 & 0.004304 & 0.008216 & 0.083529 & 1.909091 & 7.237288 & 232.3636 \\
\hline 8.50 & 53.34 & 2.25 & 0.38 & 0.25 & 0.71 & 0.35 & 0.013311 & 0.004687 & 0.042182 & 0.352113 & 5.921053 & 75.12676 \\
\hline 9.50 & 52.72 & 3.56 & 0.54 & 0.42 & 0.62 & 0.05 & 0.011760 & 0.007967 & 0.067527 & 0.677419 & 6.592593 & 85.03226 \\
\hline 10.00 & 53.12 & 2.25 & 0.63 & 0.54 & 0.66 & 0.10 & 0.012425 & 0.010166 & 0.042357 & 0.818182 & 3.571429 & 80.48485 \\
\hline 10.50 & 51.24 & 4.21 & 0.52 & 0.44 & 0.96 & 0.15 & 0.018735 & 0.008587 & 0.082162 & 0.458333 & 8.096154 & 53.37500 \\
\hline 11.00 & 52.67 & 3.2 & 0.64 & 0.46 & 0.82 & 0.06 & 0.015569 & 0.008734 & 0.060756 & 0.560976 & 5.000000 & 64.23171 \\
\hline 11.40 & 52.85 & 3.71 & 0.8 & 0.47 & 0.42 & 0.08 & 0.007947 & 0.008893 & 0.070199 & 1.119048 & 4.637500 & 125.8333 \\
\hline 12.00 & 52.02 & 3.14 & 0.65 & 0.52 & 0.69 & 0.15 & 0.013264 & 0.009996 & 0.060361 & 0.753623 & 4.830769 & 75.39130 \\
\hline 12.50 & 51.10 & 4.19 & 0.74 & 0.46 & 1.2 & 0.14 & 0.023483 & 0.009002 & 0.081996 & 0.383333 & 5.662162 & 42.58333 \\
\hline 13.00 & 51.25 & 4.25 & 0.48 & 0.37 & 0.92 & 0.05 & 0.017951 & 0.007220 & 0.082927 & 0.402174 & 8.854167 & 55.70652 \\
\hline 13.50 & 51.20 & 4.71 & 0.62 & 0.38 & 0.72 & 0.06 & 0.014063 & 0.007422 & 0.091992 & 0.527778 & 7.596774 & 71.11111 \\
\hline 14.00 & 50.61 & 5.98 & 0.56 & 0.44 & 0.6 & 0.13 & 0.011855 & 0.008694 & 0.118158 & 0.733333 & 10.67857 & 84.35000 \\
\hline 14.50 & 43.72 & 18.18 & 0.79 & 0.63 & 0.63 & 0.26 & 0.014410 & 0.014410 & 0.415828 & 1.000000 & 23.01266 & 69.39683 \\
\hline 15.00 & 53.29 & 2.27 & 0.36 & 0.24 & 0.82 & 0.07 & 0.015388 & 0.004504 & 0.042597 & 0.292683 & 6.305556 & 64.98780 \\
\hline 15.50 & 48.12 & 11.7 & 0.58 & 0.41 & 0.68 & 0.18 & 0.014131 & 0.008520 & 0.243142 & 0.602941 & 20.17241 & 70.76471 \\
\hline 16.00 & 48.14 & 9.34 & 0.57 & 0.33 & 0.53 & 0.28 & 0.011010 & 0.006855 & 0.194017 & 0.622642 & 16.38596 & 90.83019 \\
\hline
\end{tabular}


Table 7. Summary of carbonate petrography of the limestone.

\begin{tabular}{|c|c|c|c|c|c|c|c|c|}
\hline \multirow{2}{*}{$\begin{array}{c}\text { Sample } \\
\text { No }\end{array}$} & \multirow{2}{*}{$\begin{array}{c}\text { Depth } \\
(\mathrm{m})\end{array}$} & \multicolumn{4}{|c|}{ Allochems (and\% Composition) } & \multirow{2}{*}{ Sparite } & \multirow{2}{*}{ Micrite } & \multirow{2}{*}{ Support } \\
\hline & & Bioclasts & Intraclasts & Pellets & Ooids & & & \\
\hline A2 & 12.0 & $\begin{array}{l}\text { Sponge spicules, pelecypods, algae, } \\
\text { echinoids, shell fragments, } \\
\text { gastropods ( } 48 \%)\end{array}$ & $\begin{array}{l}\text { Intraclasts } \\
(2 \%)\end{array}$ & $\begin{array}{l}\text { Few } \\
(2 \%)\end{array}$ & $\begin{array}{l}\text { Few } \\
(2 \%)\end{array}$ & $\begin{array}{l}\text { Present as infill } \\
\text { within bioclasts, } \\
(6 \%)\end{array}$ & $\begin{array}{l}\text { Present as } \\
\text { matrix, }(40 \%)\end{array}$ & Micrite \\
\hline B2 & 15.0 & $\begin{array}{l}\text { Coralline algae, gastropods, algae, } \\
\text { corals, pelecypods, foraminifera, shell } \\
\text { fragments, sponge spicules, }(35 \%)\end{array}$ & $\begin{array}{l}\text { Present } \\
(15 \%)\end{array}$ & $\begin{array}{l}\text { Present } \\
(3 \%)\end{array}$ & $\begin{array}{l}\text { Few } \\
(2 \%)\end{array}$ & $\begin{array}{l}\text { Present as infill and } \\
\text { matrix components, } \\
(10 \%)\end{array}$ & $\begin{array}{l}\text { Present as } \\
\text { matrix, }(35 \%)\end{array}$ & Micrite \\
\hline $\mathrm{C} 2$ & 19.0 & $\begin{array}{l}\text { Gastropods foraminifera, algae mat, } \\
\text { echinoid, shell fragments, sponge } \\
\text { spicules, }(36 \%)\end{array}$ & $\begin{array}{l}\text { Present } \\
(10 \%)\end{array}$ & $\begin{array}{l}\text { Present } \\
(6 \%)\end{array}$ & $\begin{array}{l}\text { Few } \\
(2 \%)\end{array}$ & $\begin{array}{l}\text { Present as infill and } \\
\text { matrix components, } \\
(6 \%)\end{array}$ & $\begin{array}{l}\text { Present as } \\
\text { matrix, }(40 \%)\end{array}$ & Micrite \\
\hline
\end{tabular}

Submit or recommend next manuscript to SCIRP and we will provide best service for you:

Accepting pre-submission inquiries through Email, Facebook, LinkedIn, Twitter, etc. A wide selection of journals (inclusive of 9 subjects, more than 200 journals) Providing 24-hour high-quality service User-friendly online submission system Fair and swift peer-review system Efficient typesetting and proofreading procedure Display of the result of downloads and visits, as well as the number of cited articles Maximum dissemination of your research work

Submit your manuscript at: http://papersubmission.scirp.org/ Orcontact ojg@scirp.org 